\title{
Synthetic and Biological Surfactants Used to Mitigate Biofouling on Industrial Facilities Surfaces
}

\author{
Maria da Gloria C. da Silva ${ }^{1,2}$ (D), Leonie Asfora Sarubbo ${ }^{2,3}, *$ (D) \\ 1 Universidade Federal Rural de Pernambuco (UFRPE) - Rede nordeste de Biotecnologia (RENORBIO), Rua Dom Manoel \\ de Medeiros, s/n, Dois Irmãos, CEP: 52171-900, Recife, Pernambuco, Brasil; gloria.biotecnologia@gmail.com \\ (M.G.C.S.); \\ 2 Instituto Avançado de Tecnologia e Inovação (IATI), Rua Potyra, 31, CEP 50751-310, Recife, Brasil; \\ leonie.sarubbo@iati.org.br (L.A.S.); \\ 3 Universidade Católica de Pernambuco (UNICAP), Rua do Príncipe, 526, CEP 50050-900, Recife, Brasil; \\ leonie.sarubbo@unicap (L.A.S.); \\ * Correspondence: leonie.sarubbo@unicap.br (L.A.S.);
}

Scopus Author ID 57191500517

Received: 21.04.2021; Revised: 28.05.2021; Accepted: 2.06.2021; Published: 24.06.2021

\begin{abstract}
The adhesion of organisms to surfaces is an event that occurs in natural and artificial systems and is commonly known as bio-encrustation. The elimination of biofouling through less aggressive and ecological methods has aroused the interest of researchers and industries worldwide. Among the products with the greatest potential for altering surfaces, surfactants act at cell-cell and cell-surface interfaces, reducing surface hydrophobicity, the adherence of microorganisms, and the formation of biofilms. Biological surfactants have stood out for their versatility and proven effectiveness in recent years as valuable tools, especially due to their biodegradable characteristics when compared to synthetic surfactants. Thus, they can transform and modernize biotechnology by providing more robust antifouling technologies. This review discusses the possible roles and applications of synthetic and biological surfactants from different sources, such as biofouling reducing agents, addressing the potential alteration of surfaces, reducing surface tension, biological activities (antimicrobial, antibiofilm, and anti-adherence), biodegradability, and anticorrosion activity. Market trends and the potential uses of these multifunctional biomolecules in biofouling control are also cited, along with examples from the literature using biosurfactants as antifouling agents.
\end{abstract}

Keywords: surfactants; biosurfactants; antimicrobial activity; antiadhesive action; anticorrosion effect; antibiofilm.

(c) 2021 by the authors. This article is an open-access article distributed under the terms and conditions of the Creative Commons Attribution (CC BY) license (https://creativecommons.org/licenses/by/4.0/).

\section{Introduction: Fouling is a problem, and eco-friendly solutions are needed}

Fouling is a natural process or may be facilitated by the actions of living organisms. Such a process emerges on the surface of artificial structures or other living beings, occurring in both open environments and closed spaces. All that is needed is the presence of moisture, particles carried by air, and a fouling agent [1-4].

Biological fouling is denominated in biofouling (BF) and caused by the most varied living organisms [5-7]. Biofouling is difficult to eliminate from the environment. Conventional cleaning treatments are used but require the concomitant use of different control methods [812]. Biofouling causes harm to industries, such as mechanical, functional, and structural changes to equipment (e.g., the clogging of the pores of ultrafiltration membranes) and the wear of materials, such as the destruction of pipes due to microbiologically influenced 
corrosion (MIC) and the chemical alteration of products (e.g., fuels) [3,13-15]. Many of these sectors employ antifouling coatings, cleaning agents, or biocide solutions, which only relieve the problem for a short period. Moreover, many of these products are recalcitrant, and there is often no control over the discarding process. This leads to the contamination of water bodies, soil, and crops; it can produce biochemical changes in phytoplankton and zooplankton physiology and have carcinogenic and teratogenic effects on mollusks such as oysters and shellfishes $[2,9,16,17]$.

Thus, studies on this issue have focused on diverse strategies, such as searching for substances and materials with antifouling properties that impede or delay the adherence process $[3,11,18,19]$.

Synthetic surfactants are commonly used as cleaning or sanitizing agents in fields plagued with biofouling. These tensioactive agents are useful washing materials and contribute to the maintenance of equipment and utensils [20,21]. However, the frequent use of these surfactants is associated with toxicity problems to the local environment [22-27].

Surfactants are substances with useful properties, such as dual affinity (capacity to unite to compounds with different polarities) and reduce the surface tension of the surrounding medium [28-30]. Due to these aspects, surfactants have been exploited in different applications by the petroleum, environmental, food, and biomedical industries [28-31]

Stratistics Market Research Consulting published 'Surfactants - Global Market Outlook (2017-2026)', in which it states that the global market of surfactants produced by BASF, DowDuPont, Evonik Industries, Nouryon (previously AkzoNobel), Clariant, Huntsman, Kao, Stepan, Grupo EOC, Croda International, Sialco Materials, Aarti Industries, Enaspol, Oxiteno, KLK Oleo, Solvay, Unger Fabrikker, and Galaxy Surfactants represented US \$ 31.29 billion in 2017 and this figure is expected to reach US $\$ 58.85$ billion by 2026 , with a predicted compound annual growth rate of $7.3 \%$ [32]. With this accelerated industrial development, negative environmental changes occur on a global scale. This forces industries to seek alternatives that are less harmful to the environment and deliver new products/services that can maintain their activities and annual revenue goals. A class of natural molecules, denominated biosurfactants, emerges as a possible replacement for synthetic surfactants. Biosurfactants are compounds obtained from natural sources, such as microorganisms, plants, and animals, and have several attractive properties. Biosurfactants have attracted increasing attention due to their low toxicity, biodegradability, the possibility of production from industrial waste products, and tolerance to extreme environmental conditions. Some biosurfactants, especially glycolipids and lipopeptides, have antimicrobial properties and can prevent adherence, thereby impeding biofilm formation [33-35]. These natural compounds also have other characteristics that can be applied for the mitigation of biofouling.

This review discusses the problem of biofouling in different industrial fields, the organisms involved, as well as different prevention and mitigation strategies, highlighting the main contributions of surfactants in general and biosurfactants in particular.

\section{Biofouling is complex and causes economic losses}

Fouling is a heterogeneous process of elements - an undesirable deposition of inorganic and/or organic matter that can occur practically anywhere moisture comes into contact with exposed materials, causing the corrosion and deterioration of the affected surfaces [3]. Biofouling (biological fouling) is a natural process resulting from the activity of living organisms. Biofouling on the surface of materials is described as one of the main problems in 
marine and freshwater environments, particularly affecting maritime transport activities due to the reduction in profits caused by the increase in fuel consumption [36,37].

The environmental impact of measures used to mitigate biofouling ranges from harm caused by industrial paints with heavy metals and other toxic components to the formation of a large amount of organic waste during the cleaning process, which has harmful effects on the environment when in contact with ocean water [38]. Thus, fouling is a challenge in the fields susceptible to this phenomenon. Fouling results in functional problems, additional costs, and financial losses due to its effects on equipment and components [7,11,37,39-41]. Numerous activities that currently use maritime routes are installed at locations near abundant water or require large volumes of water themselves, such as gas and oil refineries, hydroelectric and thermoelectric plants, the food industry, and desalination activities, all of which can have materials, equipment, and devices with different fouling problems [3,42-45]. Table 1 lists the fields, problems commonly found in these fields, and related fouling agents.

Table 1. Areas favorable to fouling, main problems, and biofouling.

\begin{tabular}{|c|c|c|c|}
\hline Areas & Related issues & Main biofouling & References \\
\hline Marine & $\begin{array}{l}\text { Increased fuel consumption; } \\
\text { Wear of submerged structures; } \\
\text { Increased corrosion of structures; } \\
\text { Increased equipment maintenance } \\
\text { cost; } \\
\text { Reduced watercraft's efficiency; } \\
\text { Reduced equipment life span. }\end{array}$ & $\begin{array}{l}\text { Marine algae } \\
\text { Mussels, } \\
\text { Tubular warms, } \\
\text { Marine biofilms } \\
\text { (Pseudoalteromonas sp. } \\
\text { Pseudomonas sp., Bacillus sp.) } \\
\text { Barnacles (Ex:Balanus sp.) } \\
\text { Tubular worms }\end{array}$ & [46-48] \\
\hline Medical & $\begin{array}{l}\text { Formation of biofilms and infections } \\
\text { in catheters; } \\
\text { Periodontal diseases such as plaque } \\
\text { formation; } \\
\text { Contamination of contact lenses and } \\
\text { eye infections. }\end{array}$ & $\begin{array}{l}\text { Microorganisms and biofilms } \\
\text { Staphylococcus aureus } \\
\text { Staphylococcus epidermidis } \\
\text { Bacillus sp } \\
\text { Candida albicans } \\
\text { Streptococcus mutans } \\
\text { Escherichia coli } \\
\text { Pseudomonas aeruginosa } \\
\text { Serratia sp. }\end{array}$ & {$[18,43,49,50]$} \\
\hline Oil, Thermoelectrics, etc. & $\begin{array}{l}\text { Pipe clogging; } \\
\text { Loss of liquid pressure due to the } \\
\text { reduction of the tube diameter; } \\
\text { Corrosion in pipelines; } \\
\text { Alteration of the chemical } \\
\text { composition of the products; } \\
\text { Loss of friction in the pipes; } \\
\text { Reduced efficiency of heat exchange } \\
\text { in heat exchangers; } \\
\text { Health risk of workers due to the } \\
\text { production of toxic organic } \\
\text { compounds; } \\
\text { Continuous repairs to commercial } \\
\text { and industrial systems and } \\
\text { equipment; } \\
\text { High production cost due to } \\
\text { equipment maintenance; } \\
\text { Reduced equipment replacement } \\
\text { time; } \\
\text { Fall in the company productivity. }\end{array}$ & $\begin{array}{l}\text { Microorganisms and biofilms } \\
\text { Algae } \\
\text { Barnacles } \\
\text { Mussels } \\
\text { Tubular warms }\end{array}$ & {$[51-54]$} \\
\hline $\begin{array}{l}\text { Desalination and drinking } \\
\text { water treatment plants }\end{array}$ & $\begin{array}{l}\text { Clogging of the membrane pores; } \\
\text { Increased liquid pressure due to } \\
\text { reduced pore diameter; } \\
\text { Reduced efficiency of reverse } \\
\text { osmosis; } \\
\text { Alteration of the chemical } \\
\text { composition of the water; } \\
\text { High production cost due to } \\
\text { equipment maintenance; }\end{array}$ & $\begin{array}{l}\text { Microorganisms, biofilms and } \\
\text { algae }\end{array}$ & {$[55-58]$} \\
\hline \multicolumn{3}{|c|}{ https://biointerfaceresearch.com/ } & 2562 \\
\hline
\end{tabular}




\begin{tabular}{l|l|l|l}
\hline Areas & \multicolumn{1}{|c}{ Related issues } & Main biofouling & References \\
\hline & $\begin{array}{l}\text { Development of bacteria in drinking } \\
\text { water pipes; } \\
\text { Health risks from microbial } \\
\text { contamination; } \\
\text { Fall in company productivity. }\end{array}$ & & \\
\hline $\begin{array}{l}\text { Papermaking, food- } \\
\text { processing and sugar- }\end{array}$ & $\begin{array}{l}\text { Contamination of products; } \\
\text { alcohol industries } \\
\text { changes in the chemical composition } \\
\text { and functionality of the items; }\end{array}$ & Microorganisms and biofilms & [56,59-62] \\
& $\begin{array}{l}\text { Flow reduction in the pipes; } \\
\text { High production cost due to } \\
\text { equipment maintenance; } \\
\text { Health risk to workers by pathogenic } \\
\text { organisms; } \\
\text { Fall in company productivity. }\end{array}$ & & \\
\end{tabular}

\subsection{Different organisms are involved.}

The development of biofouling is a dynamic, highly complex process. The main agents of such a process are biofilm-forming microorganisms, such as bacteria, diatoms, fungi, and algal spores. Micro- and macroalgae and invertebrates (macro-organisms, such hydroids, barnacles, worms, and bivalves) are also reported to cause this type of problem on submerged marine surfaces. Indeed, there are more than 4,000 fouling organisms throughout the world $[3,11,63,64]$. Figure 1 is a schematic of the overall biofouling process in a metal pipe in the saline environment (A) and filtration membranes surfaces (B).

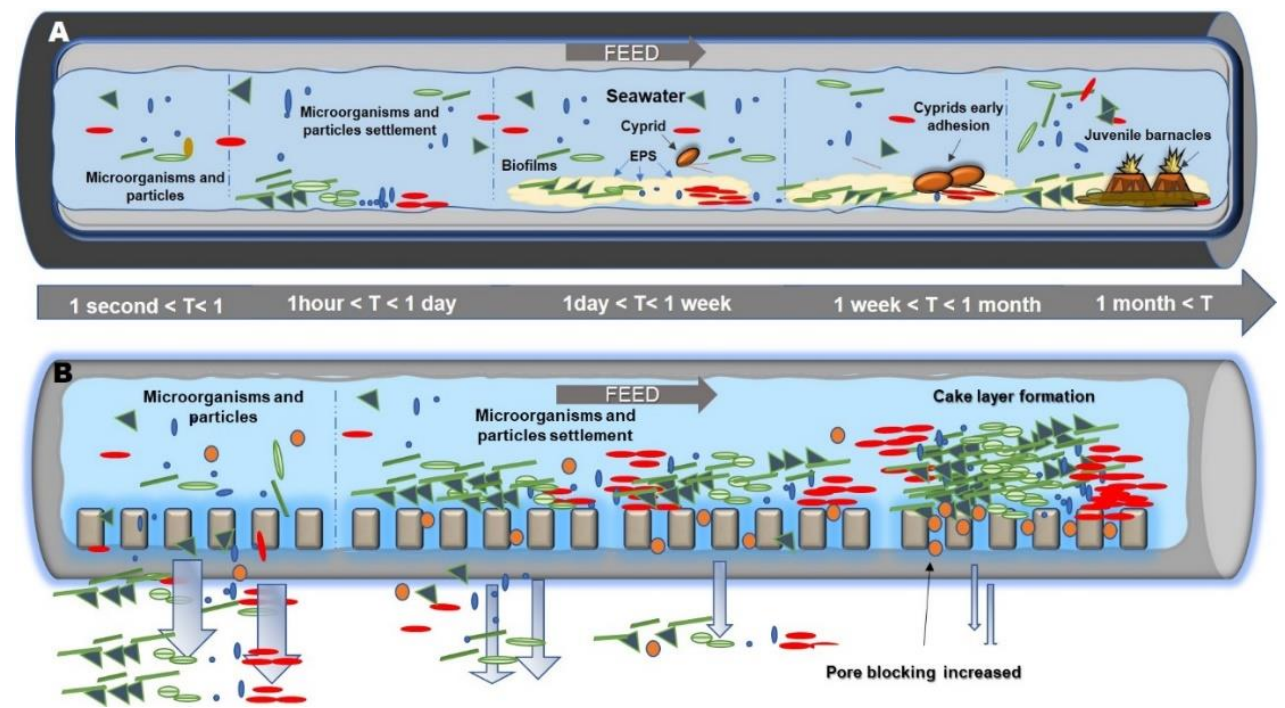

Figure 1. Outline of the overall process of biofouling in a metal pipe in a saline environment over time, the corrosion process was not highlighted in this example (A), and filtration membranes surfaces (B).

\section{Non-surfactant methods for the treatment of biofouling}

Humans have been attempting to mitigate the fouling process for more than 2000 years. Coatings with plant-based resins, tar, wax, and asphalt are cited in some of the earliest reports of coatings for the hulls of ships applied by the ancient Greeks. Different alternatives (lead, arsenic, zinc, nickel, and galvanized iron) were tested together with coatings designed to seal the iron of the copper coating [11,65]. Tributyltin-based products were once the most widely used chemical antifouling treatments and have been banned since January 2003, although these products continue to be used clandestinely in some undeveloped countries [66]. Thus, the search for less toxic or nontoxic replacements was begun [11,67-69]. 
The control of biofouling can be achieved through different physical, chemical, and biological processes or the development of materials with antiadhesive and/or antimicrobial surfaces. The combination of such techniques may also be employed [37]. Figure 2 displays a flowchart of major treatments cited in the literature. These methods tend to control the emergence of different types of biofouling on different surfaces and materials $[11,63,70]$. Treatment with biosurfactants, which is the topic of this article, appears in the figure as one of the biological methods, but it can also serve as chemical treatment, depending on the type of product developed. With physical methods, there is no use of chemical substances. With chemical treatments, injectable (biocides), free, or surface-bonded chemical products are used. In the form of paints, antifouling coatings containing biocides are the most adequate for application on watercraft surfaces, the inner part of pipes, aquiculture tanks, and offshore rigs. Biocides in their free form are generally used as cleaning agents or adjuncts of physical strategies in environments with a large amount of moisture, such as pipes and membrane filters $[2,15,69,71,72]$.

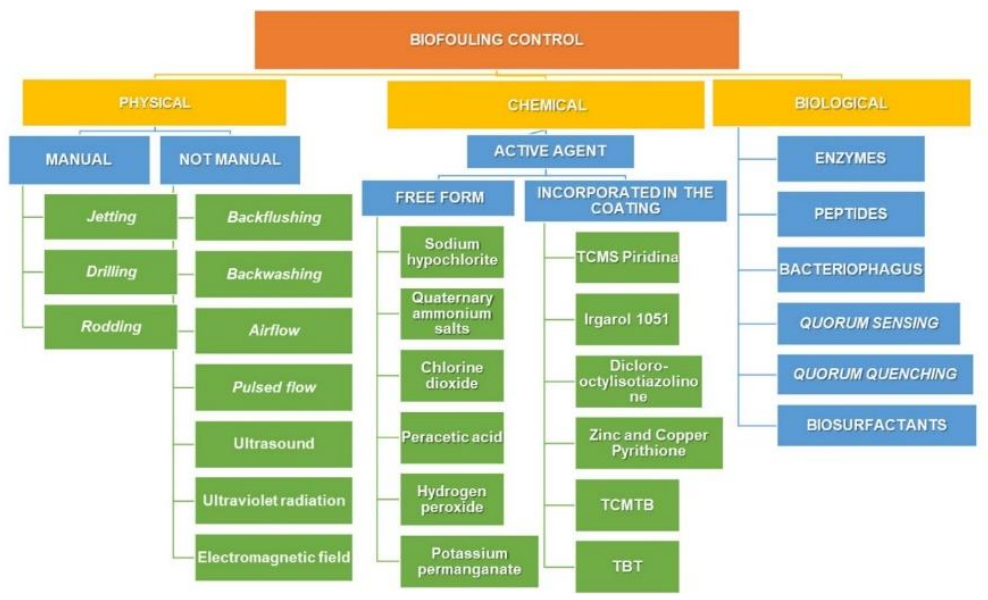

Figure 2. Flowchart representing the most common treatments cited in the literature to control the growth of different types of biofouling on different surfaces and materials.

\section{Surfactants for the control of biofouling}

Surfactants are substances often used to reduce the surface tension of a liquid and may or may not also significantly reduce interfacial tension. These are amphipathic molecules with a polar (hydrophilic) fraction and a non-polar (hydrophobic) fraction, meaning that surfactants have the dual characteristics of hydrophilicity and hydrophobicity [73,74]. Due to having an active surface with different poles in the molecule, surfactants tend to adsorb to and interact in different systems [75,76]. Surfactants are characterized by properties such as the critical micelle concentration (CMC), the hydrophilic-lipophilic balance (HLB - balance in the size and force of the hydrophilic and lipophilic portions in a surfactant molecule), chemical structure, charge, and source of origin [77-79].

There are two main types of surfactants: synthetic surfactants obtained through chemical synthesis with petroleum byproducts and natural (biological) surfactants, known as biosurfactants, which are produced by microorganisms, plants, and animals using biotechnology [30,80-82].

\subsection{Synthetic surfactants, directly and indirectly, contribute to the control of biofouling.}

Synthetic surfactants derived from petroleum products are widely employed as detergents, emulsifiers, humectants, foaming agents, and dispersants in the petrochemical 
industry as well as in the composition of hygiene products, cosmetics, foods, and fabric softeners. Surfactants also have clinical use, especially for the treatment of wounds. Commercially available surfactants include fatty acids, ester sulfonates or sulfates (anionic), and quaternary ammonium salts (cationic) [30,83-86]. In surfactants of a synthetic origin, the non-polar portion is formed by polycyclic aromatic or aliphatic hydrocarbon, whereas the polar portion may be ionic, non-ionic, or amphoteric [75,76]. The relative contributions of each portion determine the relative hydrophobicity of the molecule [87]. Amphiphilic copolymers with hydrophobic and hydrophilic groups have excellent antifouling properties [69].

In biofouling control, surfactants are generally used as disinfectants and surface cleaning agents, which in most cases aim for biofilm removal. For such, these products anchor their hydrophobic units to the surface of the dirt and maintain their hydrophilic portions aligned in the direction of the volume of the aqueous phase, leading to the removal of the dirt $[84,85,88]$. Disinfectants significantly reduce the microbial burden and eliminate pathogens [89]. Surfactants are also widely used for the removal of fouling on different types of membranes [80]. The pre-contact of surfaces can lead to the adsorption of some residues of surfactants on the surface, which can affect the development in biofilm in two ways: i) modification of biofilm formation capacity, as surfactants can counteract cell metabolism, either favoring or hindering the adherence forces that maintain the mechanical stability of the biofilm; and/or ii) the development of biofilms of a less cohesive characteristic that can lead to the detachment of the biomass [69].

\subsubsection{Quaternary ammonium compounds (QACs).}

Cationic surfactants are often used as bactericides, hair conditioners, and fabric softeners [29,85,90-93].

Table 2. Commercial chemical treatments containing quaternary ammonium compounds (QACs) and poly quaternary compounds for combating fouling.

\begin{tabular}{|c|c|c|c|c|}
\hline $\begin{array}{l}\text { Quaternary } \\
\text { surfactant } \\
\text { Trade name and } \\
\text { chemical name }\end{array}$ & Mode of action & Application & Toxicity & References \\
\hline $\begin{array}{l}\text { Bulab }^{\circledR} \quad 6002- \\
\text { Poly [oxyethylene } \\
\text { (dimethyliminio) } \\
\text { ethylene } \\
\text { dichloride] }\end{array}$ & $\begin{array}{l}\text { As a cationic } \\
\text { polymer, it binds to } \\
\text { negatively charged } \\
\text { surfaces, including } \\
\text { microorganisms and } \\
\text { shellfish } \\
\text { membranes. }\end{array}$ & $\begin{array}{l}\text { This product is used to control algae in } \\
\text { swimming pools and as a microbicide to } \\
\text { control microorganisms in commercial } \\
\text { and industrial water systems. It is also an } \\
\text { effective molluscicide and can prevent } \\
\text { biological fouling by mollusks. }\end{array}$ & $\begin{array}{l}\text { Toxic to fish, } \\
\text { mussels, and } \\
\text { other aquatic } \\
\text { organisms. }\end{array}$ & [94] \\
\hline $\begin{array}{l}\text { Bulab }^{\circledR} \quad 6086 \quad \text { - } \\
\text { Alkyl chloride } \\
(\mathrm{C} 12-16) \\
\text { dimethyl benzyl } \\
\text { ammonium. }\end{array}$ & $\begin{array}{l}\text { As a cationic } \\
\text { surfactant, it binds } \\
\text { to negatively } \\
\text { charged surfaces, } \\
\text { including } \\
\text { microorganisms and } \\
\text { mollusk membranes. }\end{array}$ & $\begin{array}{l}\text { This product is used for algae control in } \\
\text { commercial and industrial recirculating } \\
\text { cooling water towers and wastewater } \\
\text { systems. It is also used to control mollusks } \\
\text { in fresh and saltwater cooling systems. }\end{array}$ & $\begin{array}{l}\text { Toxic to fish, } \\
\text { oysters, } \\
\text { shrimp and } \\
\text { aquatic } \\
\text { invertebrates. }\end{array}$ & [94] \\
\hline $\begin{array}{l}\text { Slimicide }{ }^{\mathrm{TM}} \mathrm{C}-74 \text { - } \\
\text { Dodecylguanidine } \\
\text { hydrochloride and } \\
\text { N-Alkyl } \\
\text { dimethylbenzyl } \\
\text { ammonium } \\
\text { chloride }\end{array}$ & $\begin{array}{l}\text { The compounds } \\
\text { destroy the gills of } \\
\text { the mollusks. }\end{array}$ & $\begin{array}{l}\text { This product is used to control mollusks } \\
\text { in cooling water recirculation systems, } \\
\text { single-pass industrial cooling water } \\
\text { systems, auxiliary water systems and } \\
\text { wastewater systems. }\end{array}$ & $\begin{array}{l}\text { Toxic to fish } \\
\text { and wildlife. }\end{array}$ & [94] \\
\hline
\end{tabular}


Quaternary ammonium compounds (QACs) are cationic surfactants with a surface-bonding activity that produce antifouling biocidal effects. The pre-conditioning of surfaces with a traditional QAC [cetyltrimethylammonium bromide (CTAB)], and a new series of fluorinated QACs reduces the respiratory activity of biofilms [26]. QACs and ammonium polyquaternium are widely used classes of organic disinfectants. QACs are organic salts that have a wide variety of uses in the industry. As a cationic surfactant, Bulab ${ }^{\circledR} 6086$ bonds to negatively charged surfaces, including those of microorganisms and the membranes of mollusks [94]. QACs are mainly used as disinfectants and antiseptic formulations in homes as well as animal health, agriculture, and industrial installations. These compounds are effective against a variety of bacteria, fungi, and viruses at very low concentrations. Table 2 lists commercial chemical treatments containing (QACs) and commercial ammonium polyquaternium used for combating biofouling.

\subsubsection{Anionic and non-ionic surfactants.}

Soaps and detergents belong to the group of anionic surfactants. Sodium dodecyl sulfate (SDS) is an anionic surfactant with hydrophilic properties and hydrophobic groups, making it semi-soluble in organic and aqueous solvents. Anionic surfactants, such as SDS, together with a strong chelating agent, such as ethylenediaminetetraacetic (EDTA), affect the fouling layer, weakening the forces of cohesion between the fouling agents as well as between the fouling agents and the membrane surface. SDS solubilizes macromolecules by forming micelles, which assists in removing impurities from the surface of the membrane [95].

The synthetic anionic detergents commonly used in cleaning products contain linear sodium alkylbenzene sulfonate. These detergents are a mixture of alkylbenzene sulfonates, in which the main component is SDS, which is established as the standard of a biodegradable anionic detergent [93]. The treatment of biofilms with chemical products and surfactants, such as CTAB, ortho-phthalaldehyde (OPA), sodium hydroxide, and sodium hypochlorite, promote the weakening of the mechanical stability of biofilm [26].

Table 3. Commercial antifouling products containing surfactant substances in their formulations as an active or adjuvant.

\begin{tabular}{|c|c|c|c|}
\hline $\begin{array}{l}\text { Chemical } \\
\text { treatment }\end{array}$ & $\begin{array}{c}\text { Commercial antifouling } \\
\text { products that contain } \\
\text { surfactant }\end{array}$ & $\begin{array}{c}\text { Types of biofouling that fight } \\
\text { and/or inhibit }\end{array}$ & References \\
\hline Bromine & $\begin{array}{c}\text { ACTI-BROM }^{\circledR} 1338 \\
\text { SPECTRUS }^{\circledR} \text { OX1201 }\end{array}$ & Mussels (mollusk) & [94] \\
\hline \multirow{6}{*}{$\begin{array}{l}\text { Quaternary } \\
\text { Ammonium and } \\
\text { Polyquaternary } \\
\text { Compounds }\end{array}$} & BULAB $^{\circledR} 6002$ & Mussels & \multirow{6}{*}[94]{} \\
\hline & BULAB $^{\circledR} 6086$ & Mussels & \\
\hline & Clam-Trol CT-2 & Mussels & \\
\hline & H-130 Microbiocide & Bacteria, fungi, algaes, mussels & \\
\hline & Slimicide ${ }^{\mathrm{TM}} \mathrm{C}-74$ & Mussels & \\
\hline & VeliGON & Mussels & \\
\hline $\begin{array}{c}\text { Aromatic } \\
\text { hydrocarbons }\end{array}$ & Mexel $^{\circledR} 432 / 0$ & $\begin{array}{c}\text { Bacteria, fungi, algaes, barnacles, } \\
\text { mussels }\end{array}$ & [94] \\
\hline
\end{tabular}

The MEXEL® company (http://www.mexel432.com/en/) presents its product MEXEL® 432 as a film that acts on the molecular level as a biodegradable, non-oxidant, tensioactive emulsion with dispersant properties that avoids micro- and macro-fouling, corrosion, and slime, serving as an antifouling, anticorrosion, mud-dispersant, and musselrepellent agent. The company also reports that the emulsion enhances thermal efficiency and 
protects the environment. Table 3 lists commercial antifouling products containing surfactants in their formulations as the active ingredient or an adjuvant that combat biofilms, mussels, and barnacles.

As we have seen, surfactants are important cleaning agents and are widely used in the field of biofouling. These compounds are often considered harmless based on their biodegradability and are speculated to have low environmental concentrations. However, most surfactants are derived from chemical sources and easily accumulate in humans, animals, soil, and water [96]. Visible manifestations of the toxicity of surfactants are seen in microbes, plants, and animals. It is important to make the correct choice of surfactants, especially those free of phosphates and ecologically friendly [31]. Surfactants not made from petrochemicals are needed, and the increase in research on natural replacements for these chemical surfactants is extremely relevant. Thus, greater attention has been given to biosurfactants and the identification of their possible applications [97-99].

\subsection{Biosurfactants $(B S)$ are multifunctional biomolecules that can replace synthetic} surfactants.

Biosurfactants are surfactants of a non-petrochemical origin that also reduce surface and interfacial tensions between different elements. These are a group of structurally diverse molecules classified mainly based on their origin (microorganism, plant, or animal) and chemical structure [77,80,82,97,100-102].

Biosurfactants are the products of microbial metabolism or are obtained from the extraction of plant elements with secondary activities [86,98] and have several advantages over synthetic surfactants, such as biodegradability (easily decomposed by microorganisms), low toxicity (Lethal Dosis $=50$ ), the availability of substrates (produced from industrial waste products and/or inexpensive materials), tolerance to a wide range of temperatures and $\mathrm{pH}$, tolerance to salinity, surface and interfacial activity (lowering surface tension), biocompatibility with diverse organisms and digestibility. These natural compounds are also used as biopesticides and employed in biomedical applications (antimicrobial, anticarcinogen, antiadhesive activities; immunological adjuvants, antiviral activity, gene delivery), the food industry, cosmetics, and oil recovery activities. Biosurfactants can be employed in products and materials as emulsifiers, demulsifiers, wetting agents, foaming agents, dispersants, and detergents and can be used as functional food additives and ingredients [103-108]. Due to their unique properties, these surface-active biomolecules have attracted considerable interest in recent years [77]. Studies also indicate the possibility of employing modern genetic, molecular tools to design new products and formulations and enhance the compatibility of these biomolecules with chemical and biological products [87]. Unfortunately, however, the production of biosurfactants is not yet economically viable compared to their synthetic counterparts $[77,109]$.

\subsubsection{Biosurfactants are a structurally diverse group of molecules.}

Biosurfactants include simple molecules, such as phospholipids and fatty acids, glycolipids, lipopeptides, and high molecular weight polymers, such as lipopolysaccharides. Within the molecule, the part that is soluble in water may be a carbohydrate, amino acid, cyclic peptide, phosphate, carboxyl acid, or alcohol, whereas the hydrophobic portion may be saturated unsaturated, hydroxylated, or branched long-chain fatty acids or other structures 
$[31,81,110]$. Biosurfactants include a wide variety of tensioactive compounds, such as glycolipids, lipopeptides, polysaccharide-protein complexes, phospholipids, fatty acids, and neutral lipids [99]. The most widely known biosurfactants obtained from microorganisms are glycolipids produced by Pseudomonas sp. and Candida sp. and lipopeptides produced by Bacillus sp. [98,111,112]. The most widely studied plant-based biosurfactants are saponins obtained from plant species such as ginseng (Panax ginseng), soapbark (Quillaja saponaria Molina), soybean (Glycine max L.), chickpea (Cicer arietinum L.), and asparagus (Asparagus officinalis) $[86,113,114]$. Biosurfactants of animal origin are from bovine and porcine sources. In the United States (beractant, calfactant, and poractant alpha) have been evaluated for the treatment of respiratory distress syndrome in premature infants [115]. Biosurfactants can also be classified based on molecular weight: low molecular weight tensioactive agents (biosurfactants) and high molecular weight tensioactive agents (bioemulsifiers) [116].

Rhamnolipids (RHLs) are produced by the bacterium $P$. aeruginosa and consist of a main glycosyl group and a fatty acid tail (e.g., a rhamnose portion and 3-hydroxydecanoic acid). Their extraordinary biological and surface activities make RHLs adequate for direct application in different industries [117]. Reviews performed by Chong and $\mathrm{Li}$ [118], Lovaglio et al. [119], and Müller et al. [120] offer an overview of the production of different raw materials, diverse applications, and strategies for the dissemination of these surfactants in the market. The literature suggests that a considerable number of publications and patents have been dedicated mainly to glycolipid biosurfactants of the RHL class, which have been studied in detail [121].

Sophorolipids are produced by different non-pathogenic species of yeasts and are therefore preferable for use in food production. As a rule, these biosurfactants are produced by yeasts of the genus Candida. Indeed, Candida bombicola is the most widely used to produce sophorolipids, which occur in two forms: lactonic and acidic [122].

Table 4. Classification and types of biosurfactants produced by different organisms.

\begin{tabular}{|c|c|c|}
\hline $\begin{array}{l}\text { Classes } \\
\text { Glycolipides }\end{array}$ & Biosurfactant types & $\begin{array}{c}\text { Producing microorganisms } \\
\end{array}$ \\
\hline \multirow[t]{3}{*}{ Glycolipides } & Rhamnolipids & Pseudomonas aeruginosa \\
\hline & Trehalolipids & Mycobacterium tuberculosis \\
\hline & Sophorolipids & $\begin{array}{l}\text { Candida apicola, } \\
\begin{array}{l}\text { C.bombicola, Rhodorogula bogoriensis } \\
\text { gropengiesseri }\end{array}\end{array}$ \\
\hline $\begin{array}{l}\text { Lipopeptides and } \\
\text { lipoproteins }\end{array}$ & $\begin{array}{l}\text { Surfactin, Iturin, Fengicin and } \\
\text { Liquenisin }\end{array}$ & $\begin{array}{l}\text { Bacillus subtilis } \\
\text { Bacillus licheniformis }\end{array}$ \\
\hline $\begin{array}{l}\text { Fatty acids, } \\
\text { phospholipids and } \\
\text { neutral lipids }\end{array}$ & $\begin{array}{l}\text { Corynomycolic acid } \\
\text { Spiculisporic acid } \\
\text { Phosphatidylethanolamine }\end{array}$ & $\begin{array}{l}\text { Corynebacterium lepus; Penicillium spiculisporum } \\
\text { Acinetobacter } \\
\text { Acinetobacter sp., Rhodococcus erythropolis }\end{array}$ \\
\hline $\begin{array}{l}\text { Polymeric } \\
\text { biosurfactants }\end{array}$ & $\begin{array}{l}\text { Emulsan } \\
\text { Liposan } \\
\text { Mannoprotein }\end{array}$ & $\begin{array}{l}\text { Acinetobacter sp } \\
\text { Yarrowia lipolytica; } \\
\text { Candida lipolytica } \\
\text { Saccharomyces cerevisiae }\end{array}$ \\
\hline $\begin{array}{l}\text { Particulate } \\
\text { biosurfactants }\end{array}$ & $\begin{array}{l}\text { Extracellular vesicles } \\
\text { Whole microbial cells }\end{array}$ & $\begin{array}{l}\text { Acinetobacter sp. } \\
\text { Some Cyanobacteria }\end{array}$ \\
\hline Vegetal biosurfactants & Saponins & $\begin{array}{l}\text { Panax ginseng (ginseng), Quillaja saponária (Quillaja } \\
\text { saponaria Molina), (soybean) Glycine max (L.), Cicer } \\
\begin{array}{l}\text { arietinum (L.) (chickpea) and Asparagus officinalis } \\
\text { (asparagus) }\end{array}\end{array}$ \\
\hline Animal biosurfactants & $\begin{array}{l}\text { Beractant and } \\
\text { Calfactant } \\
\text { Poractant }\end{array}$ & Oxen \\
\hline
\end{tabular}

Lipopeptides produced by Bacillus sp. are generally divided into three groups (surfactin, iturin, and fengycin) based on the specific peptide chain and fatty acid structures. Surfactin, which is a cyclic lipopeptide composed of seven amino acids, is mainly produced by 
Bacillus subtilis. Its hydrophobic portion is composed of a long chain of 13 to 15 carbon atoms. Surfactin has antimicrobial, antibacterial, hemolytic, and antiviral activities as well as pore formation capacity, which are considered useful for industrial applications [123,124]. Table 4 offers a summary of the main biosurfactants.

4.2.2. Biosurfactants have useful properties for application as antifouling agents.

The unique properties of biosurfactants compared to their chemically synthesized counterparts and the wide availability of substrates make these biomolecules adequate for commercial applications [110]. The distinctive characteristics of biological surfactants are related to their biological activities, surface activity, tolerance to a range of $\mathrm{pH}$ values and temperatures, tolerance to ionic strength, biodegradability, low toxicity, emulsifying and demulsifying capacity, and antimicrobial activity [81,116]. Figure 3 shows the actions of these molecules in terms of changes in surfaces and biological activities (antimicrobial, antibiofilm, and anti-adherence).

By reducing the surface tension between liquids and the air, surfactants enable greater penetration of different fluids, such as solvents and antimicrobial agents [29,85,90-92]. Biosurfactants spontaneously adsorb to surfaces, altering properties such as wettability and charge [28,125-128]. Reducing tension also exerts an influence on the wettability, making surfaces hydrophilic and facilitating the cleaning process in cases of fouling. Several factors are important to the adherence of fouling organisms. In microorganisms, the role of physicochemical factors [surface characteristics (hydrophobicity, roughness, and electrical charge), temperature, $\mathrm{pH}$, water activity, salinity, pressure, oxygen demand, etc.] should be considered, as these aspects contribute to the regulation of the biofilm structure $[129,130]$. The influence of hydrophobicity on a number of fouling organisms has been investigated, often with mixed or conflicting results.

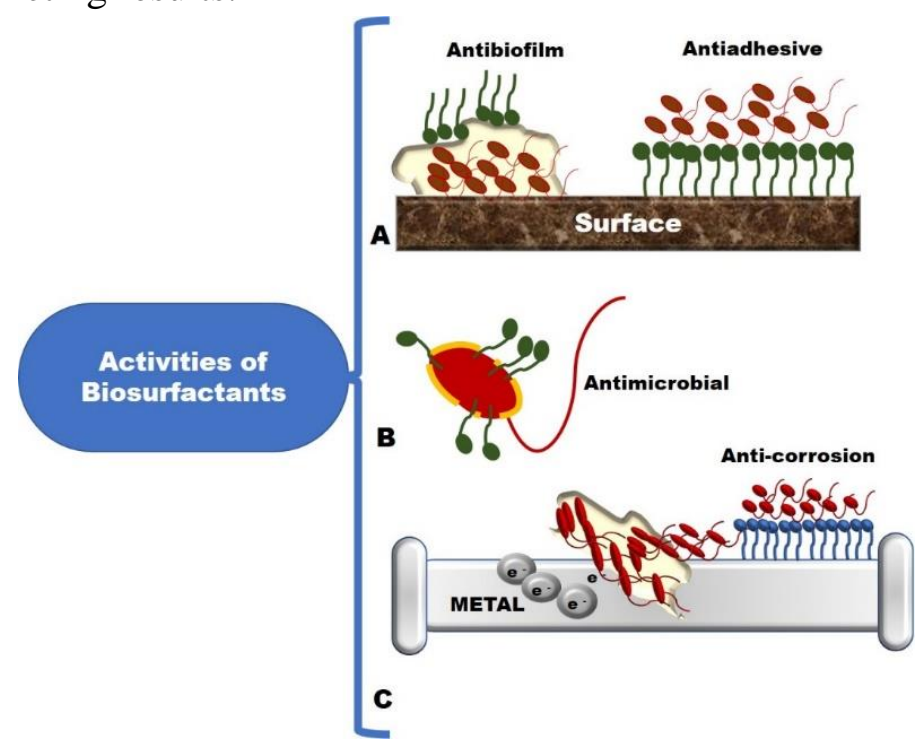

Figure 3. Activities of biosurfactants of interest in the area of biofouling. (A) Antibiofilm and anti-adhesive action; (B) Antimicrobial action and (C) anticorrosion activity.

Regarding synthetic surfactants, the negative effects of SDS on crustaceans are less pronounced, but there are reports of the harmful effects of this surfactant on the feeding habits of filtering bivalves and suspension-feeding mussels. A study addressing the effects of tetradecyltrimethylammonium bromide, sodium dodecyl sulfate, and Triton X-100 on filtering rates by marine mussels revealed that all three surfactants inhibited the filtering of food items 
in the water [131]. A toxicity study comparing the effects of a rhamnolipid to SDS on the phagotrophic alga Ochromonas danica investigated the loss of motility as well as permeability and lysis of the membrane. $O$. danica is a sensitive algal species with no protective cellular wall. The results suggest that the rhamnolipid was significantly less biolytic compared to SDS and the effects required a longer exposure time. The lysis of $O$. danica cells by the rhamnolipid was only substantial at concentrations higher than the critical micelle concentration [132].

\subsubsection{Biological activity - Antimicrobial, antibiofilm, and antiadhesive properties.}

Besides antibacterial, antiviral, and antifungal activities, biosurfactants are also good inhibitors of microbial adhesion and the consequent formation of biofilms [133-136]. The proposed mechanism of action for these biological activities suggests that biosurfactants can release the intracellular content, causing the lysis or disturbance of the cells of the target pathogen. By adhering to proteins of the membrane, biosurfactants alter the lipid content, dysregulating the osmolarity of the cell and the configuration of the cell wall, which leads to an increase in toxicity to the target organism [137-139]. Biosurfactants produced from different microorganisms have antimicrobial activity against phytopathogens and are promising biocontrol agents in the quest for sustainable farming [140]. The microbial biosurfactants most widely reported as biocontrol agents are rhamnolipids and lipopeptides. Saponins, which can come from marine or plant sources, have several biological effects, such as permeabilization of the membrane as well as immunostimulating, hypocholesterolemic, and anticarcinogenic properties [141-143]. Saponins are chemical weapons of attack or defense against microorganisms, predators, and parasites. These biomolecules are often used to investigate their antifungal, antibacterial, antifouling, anti-tumor, and anti-inflammatory activities. Researchers have even sought to produce saponin synthetically to eliminate the need for primary sources [142,144]. Surfactin A has been tested as a biocontrol agent for combating phytopathogens. This biosurfactant is reported to be an effective biocontrol agent for bakanae, a fungus that attacks rice, and should be incorporated into management strategies for this disease [145]. Biosurfactants have exhibited antagonistic effects on zoosporic phytopathogens that have acquired resistance to commercial pesticides [146]. A review performed by Santos $e t$ al. [147] offers a description of the antimicrobial, antibiofilm, and antiadhesive activities of biosurfactants of a microbial origin.

Lactic acid bacteria produce several antimicrobial compounds, such as biosurfactants, bacteriocin, hydrogen peroxide, and carbon peroxide, inhibiting pathogens' growth [148-150]. Thus, the antimicrobial, antibiofilm, and antiadhesive properties of biosurfactants produced by this group of microorganisms are of interest to the field of biofouling control. Table 5 summarizes the microorganisms, biosurfactants produced, and respective properties that could be useful in antifouling activities.

Table 5. Biosurfactants of microbial origin with possible biotechnological applications in the area of antifouling.

\begin{tabular}{c|c|c|c} 
Producing microorganism & Produced biosurfactant & $\begin{array}{c}\text { Effects and/or potential } \\
\text { biotechnological application }\end{array}$ & References \\
\hline $\begin{array}{c}\text { Pseudozyma aphidis DSM } \\
70725\end{array}$ & Mannosylerythritol lipids & $\begin{array}{c}\text { Antimicrobial and antibiofilm } \\
\text { activities }\end{array}$ & {$[151]$} \\
\hline $\begin{array}{c}\text { Acinetobacter junii B6 } \\
\begin{array}{c}\text { and Lactobacillus } \\
\text { plantarum }\end{array}\end{array}$ & Lipopeptide & $\begin{array}{c}\text { Antimicrobial, antibiofilm and } \\
\text { antiproliferative activities }\end{array}$ & {$[152]$} \\
\hline $\begin{array}{c}\text { Pediococcus acidilactici } \\
\text { https://biointerfaceresearch.com/ }\end{array}$ & $\begin{array}{c}\text { Antimicrobial, anti-adhesive and } \\
\text { antibiofilm activities }\end{array}$ & {$[150]$} \\
\hline
\end{tabular}




\begin{tabular}{|c|c|c|c|}
\hline Producing microorganism & Produced biosurfactant & $\begin{array}{c}\text { Effects and/or potential } \\
\text { biotechnological application }\end{array}$ & References \\
\hline $\begin{array}{c}\text { Bacillus subtilis VSG4 and } \\
\text { Bacillus licheniformis } \\
\text { VS16 }\end{array}$ & Lipopeptide & $\begin{array}{l}\text { Antioxidant, antibacterial and anti- } \\
\text { adhesive activities }\end{array}$ & {$[153]$} \\
\hline Halomonas sp. (BOB-3) & Rhamnolipid & Antibiofilm activity & {$[154]$} \\
\hline $\begin{array}{c}\text { Lactobacillus pentosus } \\
\text { and Lactobacillus } \\
\text { paracasei }\end{array}$ & Glycolipopeptide macromolecules & $\begin{array}{l}\text { Anti-adhesive and antimicrobial } \\
\text { activities }\end{array}$ & {$[155]$} \\
\hline Lactobacillus casei & Authors called BS - BI and BS - Z9 & $\begin{array}{c}\text { Antioxidant, antibiofilm, } \\
\text { antibacterial, anti-adhesion and } \\
\text { biofilm dispersion effects }\end{array}$ & {$[33]$} \\
\hline Burkholderia thailandesis & Rhamnolipid & $\begin{array}{l}\text { Antimicrobial activity and inhibitor } \\
\text { of biofilm formation }\end{array}$ & {$[156]$} \\
\hline $\begin{array}{l}\text { Pseudomonas aeruginosa } \\
\text { and Bacillus subtilis }\end{array}$ & Rhamnolipids and Surfactin & $\begin{array}{l}\text { Anti-adhesive, antibiofilm and } \\
\text { antimicrobial activities }\end{array}$ & [111] \\
\hline $\begin{array}{c}\text { Rhodococcus ruber } \\
\text { IEGM231 }\end{array}$ & $\begin{array}{l}\text { Glycolipids containing trehalose as } \\
\text { the hydrophilic portion }\end{array}$ & Adhesion inhibition & {$[125]$} \\
\hline $\begin{array}{l}\text { Lactobacillus agilis CCUG } \\
\qquad 31450\end{array}$ & $\begin{array}{l}\text { The authors suggest that the cell- } \\
\text { bound biosurfactant should be a } \\
\text { glycoprotein }\end{array}$ & $\begin{array}{l}\text { Anti-adhesive and antimicrobial } \\
\text { activities }\end{array}$ & [148] \\
\hline $\begin{array}{l}\text { Candida bombicola } \\
\text { ATCC } 22214\end{array}$ & Sophorolipids & $\begin{array}{l}\text { Disorder of biofilms, bactericidal } \\
\text { agent for biomedical technological } \\
\text { applications }\end{array}$ & {$[157]$} \\
\hline $\begin{array}{c}\text { Bacillus subtillis } \mathrm{C} 4, \mathrm{M} 1 \\
\text { and G2III }\end{array}$ & Surfactin & Antimicrobial activity & {$[158]$} \\
\hline $\begin{array}{l}\text { Pseudomonas aeruginosa } \\
\text { and Bacillus subtilis }\end{array}$ & Rhamnolipids and Surfactin & $\begin{array}{l}\text { Disturbance in the structure of } \\
\text { pathogenic biofilms formed by pure } \\
\text { or mixed cultures }\end{array}$ & [159] \\
\hline $\begin{array}{l}\text { Pseudomonas aeruginosa } \\
\text { and Bacillus subtilis }\end{array}$ & Rhamnolipids and Surfactin & $\begin{array}{l}\text { Anti-adhesive and antibiofilm } \\
\text { effects }\end{array}$ & [160] \\
\hline $\begin{array}{c}\text { Trichosporon } \\
\text { montevideense }\end{array}$ & $\begin{array}{l}\text { Hydrophobic side-chain glycolipid } \\
\text { or heteropolysaccharide }\end{array}$ & Inhibition of biofilm formation & {$[161]$} \\
\hline $\begin{array}{l}\text { Candida lipolytica UCP } \\
0988\end{array}$ & Rufisan & $\begin{array}{l}\text { Anti-adhesive and antimicrobial } \\
\text { activities }\end{array}$ & [162] \\
\hline $\begin{array}{c}\text { Candida sphaerica } \\
\text { UCP } 0995\end{array}$ & Lunasan & $\begin{array}{l}\text { Anti-adhesive and antimicrobial } \\
\text { activities }\end{array}$ & [163] \\
\hline $\begin{array}{c}\text { Serratia marcescens } \\
\text { acession number } \\
\text { (GQ214001) }\end{array}$ & Glycolipide & $\begin{array}{l}\text { Anti-adhesive and antimicrobial } \\
\text { activities and biofilm disturbance }\end{array}$ & {$[164]$} \\
\hline $\begin{array}{l}\text { Pseudomonas aeruginosa } \\
\text { and Pseudomonas } \\
\text { licheniformis }\end{array}$ & Rhamnolipids & Anti-adhesive effect & {$[165]$} \\
\hline $\begin{array}{c}\text { Pseudomonas aeruginosa } \\
\text { and } \\
\text { Bacillus subtilis }\end{array}$ & Rhamnolipids and Surfactin & $\begin{array}{c}\text { The anti-adhesive effect, } \\
\text { disturbance of pre-formed biofilms } \\
\text { and EPS removal }\end{array}$ & {$[166]$} \\
\hline Bacillus natto TK-1 & Lipopeptide & $\begin{array}{l}\text { Anti-adhesive, antimicrobial and } \\
\text { anti-tumor activities }\end{array}$ & [167] \\
\hline Bacillus circulans & Lipopeptide & Anti-adhesive activity & {$[168]$} \\
\hline $\begin{array}{c}\text { Pseudomonas aeruginosa } \\
\text { PAO1 }\end{array}$ & Rhamnolipid & Affects biofilm architecture & [169] \\
\hline
\end{tabular}

4.2.2.2. Biodegradability, stability, and toxicity are key characteristics of $B S$.

Olasanmi and Thring [170] highlight the biodegradability of biosurfactants. The authors explore the diverse applications and recognize biosurfactants as potential sustainable ingredients in a wide variety of commercial products. Biosurfactants are significantly less harmful to the environment than chemical surfactants, which are toxic and recalcitrant. Unlike their synthetic counterparts, biosurfactants are mineralized to $\mathrm{CO}_{2}$, and $\mathrm{H}_{2} \mathrm{O}$ by the microorganisms themselves [170]. The intense current movement toward industrial sustainability has stimulated the active interest in biosurfactants as possible alternatives to chemical surfactants. Besides being produced with the use of renewable substrates, 
biosurfactants have characteristics in line with the famous term "environmentally friendly". Moreover, the capacity to tolerate high temperatures and salt concentrations make biosurfactants attractive to numerous industrial processes and products. These natural compounds can be used in environmental cleaning processes involving the biodegradation and detoxication of industrial effluents as well as the bioremediation of contaminated soils $[171,172]$. The functional stability of biosurfactants is an extremely useful property for industrial applications, as these natural compounds have a broad range of tolerance with regards to temperature, $\mathrm{pH}$, and salinity. In contrast, chemical surfactants become inactive when submitted to extreme variations in temperature, $\mathrm{pH}$, and concentrations of sodium chloride [106,132].

The biodegradability of different biosurfactants was achieved by the release of $\mathrm{CO}_{2}$. Acinetobacter baumanni LBBMA ES11, Acinetobacter haemolyticus LBBMA 53, and Pseudomonas sp. LBBMA 101B consumed biosurfactants produced by Bacillus sp. LBBMA 111A (mixed lipopeptide), Bacillus subtilis LBBMA 155 (lipopeptide), Flavobacterium sp. LBBMA 168 (mixture of flavolipids), Dietzia maris LBBMA 191 (glycolipid), and Arthrobacter oxydans LBBMA 201 (lipopeptide) as carbon sources. SDS was also mineralized by these microorganisms but at a much lower rate [173]. The biodegradability, acute toxicity, embryonic toxicity, and cytotoxicity of synthetic monorhamnopyranosyl- $\beta$-hydroxydecanoyl$\beta$-hydroxydecanoate (Rha-C10-C10) were investigated against biosynthesized monorhamnolipid mixtures (bio-mRL). All Rha-C10-C10 and bio-mRL diastereomers were biodegradable, with mineralization ranging from 34 to $92 \%$ [174]. Acute toxicity tests performed with Daphnia magna, Vibrio fischeri, and Selenastrum capricornutum indicated that the toxicity of surfactin produced by a strain of Bacillus subtilis isolated from the soil of a Brazilian mangrove was lower than that of its chemical derivates [175].

\subsubsection{Anticorrosion activity of BS can affect MIC and protect structures.}

Numerous metals as well a nickel-based and aluminum-based alloys, are part of the composition of carbon steel and stainless steel, which are used in structures located in marine and freshwater environments, such as port installations, water cooling circuits, ships, and related equipment. When exposed to moist media, these materials are colonized by various microorganisms, which adhere and grow, forming biofilms. This fouling process is known as biocorrosion or microbiologically influenced corrosion and occurs mainly through electrochemical reactions of sulfate-reducing bacteria. This activity alters the structures and, consequently, lowers the performance of these materials [176,177]. Materials such as concrete, asphalt, polymers, coatings, as well as some oils and emulsions are also subject to microbial corrosion [136]. In a liquid medium, the anticorrosion action of surfactants occurs due to either physical (electrostatic) adsorption or chemical reactions that occur on the surface of the immersed material [178].

Studying the influence of a rhamnolipid biosurfactant complex on corrosion and the repassivation of a recently cut aluminum alloy (Al-Cu-Mg) surface, Zin et al. [179] found that the rhamnolipid effectively inhibited the corrosion of the alloy in the water of synthetic acid rain. The efficiency was credited to the adsorption of the biosurfactant. Moreover, inhibition was greater with the increase in the rhamnolipid concentration up to a certain point.

Species of Bacillus sp. synthesize a wide variety of antimicrobial surfactants, such as surfactin, iturin, and fengycin, which belong to the family of lipopeptides. These biosurfactants 
have biological activities that can be useful against sulfate-reducing bacteria [147]. Płaza and Achal [136] recently published a review on biosurfactants with anticorrosion activity.

\section{Applications of biosurfactants in fields with biofouling problems and correlates}

A search of the Scopus database in 2020 retrieved only three papers published in the last ten years addressing antifouling and biosurfactants. The studies involved analyses of the properties of the cellular surface of bacterial biofilms in seawater [180], the involvement of a rhamnolipid in cell adhesion and the development of biofilms [181], and the antibiofilm activity of biosurfactants produced by bacteria associated with corals in the Gulf of Mannar [182]. These studies focused only on the biofouling aspect of biofilms. Other studies, although not directly mentioning the term biofouling, can be analyzed as sources of information. Some of these studies demonstrated that metallic surfaces pre-conditioned with biosurfactants could strongly inhibit the microbial contamination of materials, inhibiting or reducing the subsequent development of biofilms [180] and the development of biofouling on immersed metallic structures when incorporated into paints [183]. Lipopeptide 6-2 produced by Bacillus amyloliquefaciens anti-CA ruptured the cells and protoplasts of the biofilm-forming bacteria Pseudomonas aeruginosa PAO1 and Bacillus cereus 1A06374. Lipopeptide 6-2 also inhibited biofilm formation and dispersed pre-formed biofilms. On fouling processes and algae, lipopeptide 6-2 eliminated the larvae of the barnacle Balanus amphitrite, inhibited the germination of spores of Laminaria japonica, and inhibited the growth of protozoans, all of which are fouling organisms in marine environments [184]. The lipopeptide biosurfactant produced by the SDS 21 strain exhibited bactericidal activity against plankton cells and sessile cells, eradicating more than $99 \%$ of bacterial biofilm on the surface of polystyrene, glass, and stainless steel. This biosurfactant can be used as a disinfectant or in effective disinfectant formulations against plankton bacteria or biofilm, as it maintains its bactericidal and antibiofilm activities even when exposed to extreme conditions [185].

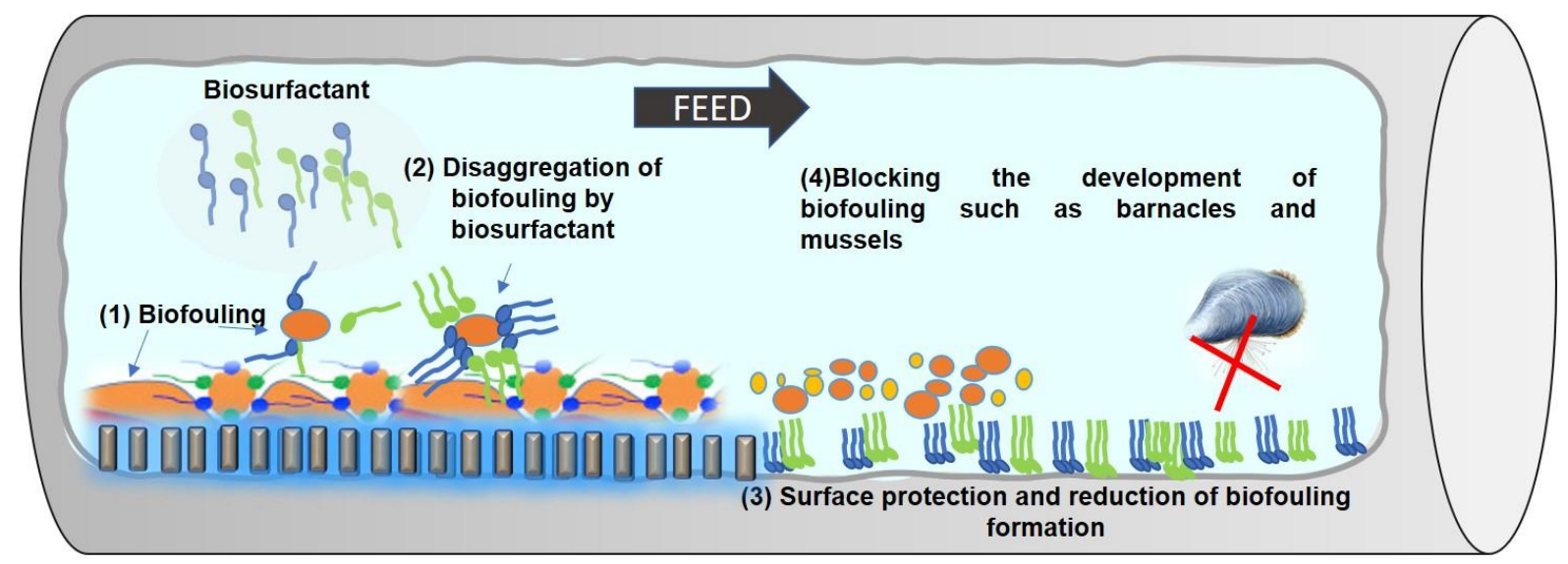

Figure 4. Schematic of the possible actions of biosurfactants in relation to mitigation of biofouling. 1-2 destructuring of incrustations such as inorganic and organic particles and biofilms in pores of filtering membranes, 3- adhesion and protection of surfaces against fouling in general and $\mathbf{4}$ - indirect inhibition of the formation of macro-fouling by antimicrobial action and interruption of chemical signal.

Many commercially available antifouling agents were developed from herbicides and pesticides. When present in this type of formulation, these substances are known as antifouling boosters [186]. Due to their larvicidal and mosquitocidal activities as well as antifungal activity against plant pathogens, glycolipids are being used as biopesticides. Besides improving the vital status of plants, glycolipids safeguard stored products from possible predators. Therefore, 
this class of biosurfactants can be used for the development of antifouling formulations [187]. The Ecover company produces a sophorolipid from Candida bombicola to clean products for rigid surfaces and clothes detergents. Jeneil industries uses a rhamnolipid from Pseudomonas aeruginosa and sells Zonix as a fungicide. MG Intobio also uses a sophorolipid from Candida bombicola in soaps $[31,188,189]$. Figure 4 displays a schematic of the possible actions of biosurfactants regarding the mitigation of biofouling.

Patents involving biosurfactants used as antifouling agents are scarce (Table 6). Such patents are related to rhamnolipids, sophorolipids, surfactin, fengycin, iturin, and lactobacilli. However, many patent seekers state that biosurfactants are being used as antimicrobial and antibiofilm agents or biocides, without explicitly mentioning antifouling activity in the patent requests.

Table 6. Patents citing biosurfactant and biofouling in their documents with biological source and applications.

\begin{tabular}{|c|c|c|c|c|c|}
\hline Biosurfactant & Biological source & Applications & Patent Title & Patent number & References \\
\hline $\begin{array}{l}\text { AAFOB- } \\
\text { 1IDA2H } \\
\text { named } \\
\text { biosurfactant }\end{array}$ & $\begin{array}{l}\text { Bacterium Cobetia } \\
\text { marina } \\
\text { (MM1IDA2H-1) }\end{array}$ & $\begin{array}{l}\text { Treatment of } \\
\text { infectious } \\
\text { pathologies in } \\
\text { aquaculture; } \\
\text { Additive and } \\
\text { Emulsifier of paints } \\
\text { and inducer of the } \\
\text { immune system of } \\
\text { fish }\end{array}$ & $\begin{array}{l}\text { The strain of Cobetia } \\
\text { marina and } \\
\text { biosurfactant extract } \\
\text { obtained from the } \\
\text { same }\end{array}$ & EP2716749A1 & {$[190]$} \\
\hline $\begin{array}{l}\text { Rhamnolipid } \\
\text { and } \\
\text { Sophorolipids }\end{array}$ & $\begin{array}{l}\text { Bacterium } \\
\text { Pseudomonas } \\
\text { aeruginosa (DS10- } \\
\text { 129) } \\
\text { Yeasts of the genus } \\
\text { Candida sp. }\end{array}$ & $\begin{array}{l}\text { Paint composition as } \\
\text { an emulsifier, } \\
\text { dispersant, and } \\
\text { biocidal additive } \\
\text { substitute. }\end{array}$ & $\begin{array}{l}\text { Aqueous coatings } \\
\text { and paints } \\
\text { incorporating one or } \\
\text { more antimicrobial } \\
\text { biosurfactants and } \\
\text { methods for using } \\
\text { the same }\end{array}$ & $\begin{array}{l}\text { US2013029646 } \\
\text { 1A1 }\end{array}$ & [191] \\
\hline $\begin{array}{l}\text { Surfactin and } \\
\text { Fengicin }\end{array}$ & $\begin{array}{l}\text { Bacillus } \\
\text { licheniformis } \\
\text { (V9T14) }\end{array}$ & $\begin{array}{l}\text { Antibiofilm and } \\
\text { antimicrobial that } \\
\text { can be used in } \\
\text { combination with } \\
\text { biocides to prevent } \\
\text { the formation and/or } \\
\text { to eradicate } \\
\text { planktonic bacteria } \\
\text { or biofilms, } \\
\text { preferably on biotic } \\
\text { and abiotic surfaces. }\end{array}$ & $\begin{array}{l}\text { Biosurfactant } \\
\text { composition } \\
\text { produced by a new } \\
\text { Bacillus licheniforms } \\
\text { strain, uses and } \\
\text { products thereof }\end{array}$ & US8377455B2 & [192] \\
\hline $\begin{array}{l}\text { Surfactin and } \\
\text { Iturin }\end{array}$ & $\begin{array}{l}\text { Bacillus } \\
\text { methylotrophicus } \\
\text { (SCSGAB0092CCT } \\
\text { CC) }\end{array}$ & $\begin{array}{l}\text { Inhibition of } \\
\text { barnacle larva } \\
\text { fixation (antifouling } \\
\text { activity), } \\
\text { antibacterial, } \\
\text { antifungal and } \\
\text { antiviral with wide } \\
\text { industrial } \\
\text { application. }\end{array}$ & $\begin{array}{l}\text { Methylotrophic } \\
\text { bacillus for } \\
\text { producing surfactins } \\
\text { and iturina. } \\
\text { Compounds and } \\
\text { application of } \\
\text { methylotrophic } \\
\text { bacillus }\end{array}$ & CN102994418B & [193] \\
\hline Not cited & Not cited & $\begin{array}{l}\text { Industrial cleaning } \\
\text { method using } \\
\text { biosurfactant and } \\
\text { electro-coating } \\
\text { systems to remove or } \\
\text { inhibit the growth of } \\
\text { microorganisms. }\end{array}$ & $\begin{array}{l}\text { Treating an } \\
\text { electrocoat system } \\
\text { with a biosurfactant }\end{array}$ & US7413643B2 & [194] \\
\hline $\begin{array}{l}\text { Biosurfactant } \\
\text { from } \\
\text { lactobacillus }\end{array}$ & $\begin{array}{l}\text { Lactobacillus } \\
\text { acidophilus } \mathrm{RC} 14\end{array}$ & $\begin{array}{l}\text { Antimicrobial, } \\
\text { Antibiofilm, } \\
\text { prevention of biofilm } \\
\text { formation on } \\
\text { surfaces. }\end{array}$ & $\begin{array}{l}\text { Lactobacillus } \\
\text { therapies }\end{array}$ & US6051552A & [195] \\
\hline
\end{tabular}




\section{Final Considerations and Future Trends}

Studies on biosurfactants specifically for combating biofouling remain scarce compared to those on the use of these biomolecules in bioremediation, oil recovery, cosmetics, pharmaceuticals, and food products.

Advancements in knowledge on interactions between micro- and macro-species in aquatic ecosystems, the role of biofilms, and adherence mechanisms to different types of surfaces can contribute to the development and improvement of technologies to inhibit biofouling.

Innovative studies are needed to replace chemically synthesized biocides as antifouling and anticorrosion agents can be replaced with eco-friendly alternatives. It is fundamental to discover novel biological pathways for producing biosurfactants on an industrial scale and obtaining products that achieve better results. Companies that need to control biofouling choose chemical products that are effective, work quickly, and have minimal environmental impact. Thus, biosurfactants are promising for fields that require the protection of surfaces, such as medical devices, immersion lenses, metal pipes, concrete, and polymers. Reducing the corrosive effect inducted by microbes on these materials is of considered interest. The literature describes applications involving intelligent antibacterial coatings that release charged or encapsulated biocides. Besides antibiotics, antimicrobial peptides and quaternary ammonium compounds are examples of such biocides [196]. Biosurfactants, such as lipopeptides, can be used for the development of intelligent antibacterial coatings. Such coatings have been widely studied to obtain materials that can line or constitute medical devices, medical installations, textiles used for hospital bedding, uniforms for patients and employees, curtains, bandages, and food packaging. Despite the numerous studies on the production of novel types of natural antifouling agents, the development of alternative, biodegradable, less toxic products containing biosurfactants is an important strategy for acquiring products that are more compatible with the environment. Many biosurfactants are useful tools for biotechnology and are advantageous for humanity. A number of patents have been issued involving biosurfactants produced by microorganisms such as Pseudomonas spp., Bacillus spp., and Candida spp., demonstrating the potential for the production and industrial application of these biomolecules.

Considering the similarities between biofilms and biofouling, the results of currently ongoing studies are expected to contribute to the development of methods that prevent the process of biofouling in the different fields affected by this phenomenon. Therefore, it is encouraging to see that there is much more room for investigations regarding the properties of biosurfactants in this respect. Important first steps have been taken by studies addressing anticorrosion and biosurfactants as herbicides, algicides, and larvicides. It is important to unite this knowledge for use in antifouling applications.

\section{Funding}

This study was funded by the Research and Development Program of the National Agency of Electrical Energy (ANEEL) and Termopernambuco Thermoelectric Plant (TERMOPE), the Foundation for the Support of Science and Technology of the State of Pernambuco (FACEPE), the National Council for Scientific and Technological Development (CNPq), and the Coordination for the Improvement of Higher Education Personnel (CAPES - Finance Code 001). 


\section{Acknowledgments}

The authors are grateful to the Centre of Sciences and Technology of the Universidade Católica de Pernambuco and the Advanced Institute of Technology and Innovation (IATI), Brazil.

\section{Conflicts of Interest}

The authors declare no conflict of interest.

\section{References}

1. Taylor, P.; Singer, I.L.; Kohl, J.G.; Patterson, M. Mechanical Aspects of Silicone Coatings for Hard Foulant Control. Biofouling 2000, 16, 301-309, http://dx.doi.org/10.1080/08927010009378453.

2. Venkatesan, R.; Sriyutha Murthy, P. Macrofouling Control in Power Plants. In Marine and industrial Biofouling, 2008; 4, 265-291, https://doi.org/10.1007/7142_2008_14.

3. Rao, T.S. Biofouling in Industrial Water Systems. In Mineral Scales and Deposits; Elsevier, 2015; 123-140, https://doi.org/10.1016/B978-0-444-63228-9.00006-1.

4. Poornima, E.H.; Rajadurai, M.; Rao, V.N.R.; Narasimhan, S.V.; Venugopalan, V.P. Use of coastal waters as condenser coolant in electric power plants: Impact on phytoplankton and primary productivity. J. Therm. Biol. 2006, 31, 556-564, https://doi.org/10.1016/j.jtherbio.2006.05.009.

5. Myan, F.W.Y.; Walker, J.; Paramor, O. The interaction of marine fouling organisms with topography of varied scale and geometry: A review. Biointerphases 2013, 8, 1-13, https://doi.org/10.1186/1559-4106-8-30.

6. Balqadi, A.A.; Salama, A.J.; Satheesh, S. Microfouling development on artificial substrates deployed in the central Red Sea. Oceanologia 2018, 60, 219-231, https://doi.org/10.1016/j.oceano.2017.10.006.

7. Abdul Azis, P.K.; Al-Tisan, I.; Al-Daili, M.; Green, T.N.; Ba-Mardouf, K.; Al-Qahtani, A.; Al-Sabai, K. Marine Macro Fouling: a Review of Control Technology in the Context of an on-Line Experiment in the Turbine Condenser Water Box of Al-Jubail Phase-I Power / Msf Plants 1. Desalination 2003, 154, 277-290, https://doi.org/10.1016/S0011-9164(03)80043-7.

8. O'Connor, N.J.; Richardson, D.L. Attachment of barnacle (Balanus amphitrite Darwin) larvae: Responses to bacterial films and extracellular materials. J. Exp. Mar. Bio. Ecol. 1998, 226, 115-129, https://doi.org/10.1016/S0022-0981(97)00242-6.

9. Henderson, P. Fouling and Antifouling in Other Industries- Power Stations, Desalination Plants- Drinking Water Supplies and Sensors, in: Biofouling. 2010, Wiley-Blackwell, Oxford, UK, 288-305. https://doi.org/10.1002/9781444315462.ch20.

10. Landoulsi, J.; Cooksey, K.E.; Dupres, V. Review - Interactions between diatoms and stainless steel : focus on biofouling and biocorrosion. Biofouling 2011, 27, 1105-1124, https://doi.org/10.1080/08927014.2011.629043.

11. Yebra, D.M.; Kiil, S.; Dam-Johansen, K. Antifouling technology—past, present and future steps towards efficient and environmentally friendly antifouling coatings. Prog. Org. Coatings 2004, 50, 75-104, https://doi.org/10.1016/j.porgcoat.2003.06.001.

12. Lekbach, Y.; Xu, D.; El Abed, S.; Dong, Y.; Liu, D.; Khan, M.S.; Ibnsouda Koraichi, S.; Yang, K. Mitigation of microbiologically influenced corrosion of 304L stainless steel in the presence of Pseudomonas aeruginosa by Cistus ladanifer leaves extract. Int. Biodeterior. Biodegradation 2018, 133, 159-169, https://doi.org/10.1016/j.ibiod.2018.07.003.

13. Flemming, H.C. Biofouling in water systems - Cases, causes and countermeasures. Appl. Microbiol. Biotechnol. 2002, 59, 629-640, https://doi.org/10.1007/s00253-002-1066-9.

14. Dafforn, K.A.; Lewis, J.A.; Johnston, E.L. Antifouling strategies: History and regulation, ecological impacts and mitigation. Mar. Pollut. Bull. 2011, 62, 453-465, https://doi.org/10.1016/J.MARPOLBUL.2011.01.012.

15. Almeida, E.; Diamantino, T.C.; de Sousa, O. Marine paints: The particular case of antifouling paints. Prog. Org. Coatings 2007, 59, 2-20, https://doi.org/10.1016/j.porgcoat.2007.01.017.

16. Venkatnarayanan, S.; Murthy, P.S.; Kirubagaran, R.; Venugopalan, V.P. Effect of chlorination on barnacle larval stages: Implications for biofouling control and environmental impact. Int. Biodeterior. Biodegrad. 2016, 109, 141-149, https://doi.org/10.1016/j.ibiod.2016.01.011.

17. Sievers, M.; Fitridge, I.; Bui, S.; Dempster, T. To treat or not to treat: a quantitative review of the effect of biofouling and control methods in shellfish aquaculture to evaluate the necessity of removal. Biofouling 2017, 
33, 755-767, https://doi.org/10.1080/08927014.2017.1361937.

18. LoVetri, K.; Gawande, P. V; Yakandawala, N.; Madhyastha, S. Biofouling and Anti-Fouling of Medical Devices. Biofouling: Types, Impact and Anti-Fouling 2010, 105-127.

19. Fitridge, I.; Dempster, T.; Guenther, J.; de Nys, R. The impact and control of biofouling in marine aquaculture: a review. Biofouling 2012, 28, 649-69, https://doi.org/10.1080/08927014.2012.700478.

20. Frota, M.N.; Ticona, E.M.; Neves, A. V.; Marques, R.P.; Braga, S.L.; Valente, G. On-line cleaning technique for mitigation of biofouling in heat exchangers: A case study of a hydroelectric power plant in Brazil. Exp. Therm. Fluid Sci. 2014, 53, 197-206, https://doi.org/10.1016/j.expthermflusci.2013.12.006.

21. Cristiani, P. Solutions to fouling in power station condensers. Appl. Therm. Eng. 2005, 25, 2630-2640, https://doi.org/10.1016/j.applthermaleng.2004.11.029.

22. Piazza, V.; Dragić, I.; Sepečić, K.; Faimali, M.; Garaventa, F.; Turk, T.; Berne, S. Antifouling activity of synthetic alkylpyridinium polymers using the barnacle model. Mar. Drugs 2014, 12, 1959-1976, https://doi.org/10.3390/md12041959.

23. Cowie, P.; Smith, M.; Hannah, F.; Cowling, M.; Hodgkeiss, T. The prevention of microfouling and macrofouling on hydrogels impregnated with either Arquad 2C-75® or benzalkonium chloride. Biofouling 2006, 22, 173-185, https://doi.org/10.1080/08927010600783296.

24. Videla, H.A. Prevention and control of biocorrosion. Int. Biodeterior. Biodegradation 2002, 49, 259-270, https://doi.org/10.1016/S0964-8305(02)00053-7.

25. Piret, J.; Desormeaux, A.; Bergeron, M.G. Sodium Lauryl Sulfate, a Microbicide Effective Against Enveloped and Nonenveloped Viruses. Curr. Drug Targets 2002, 3, 17-30, https://doi.org/10.2174/1389450023348037.

26. Simões, M.; Pereira, M.O.; Vieira, M.J. Action of a cationic surfactant on the activity and removal of bacterial biofilms formed under different flow regimes. Water Res. 2005, 39, 478-486, https://doi.org/10.1016/J.WATRES.2004.09.018.

27. Gabrus, E.; Szaniawska, D. Application of backflushing for fouling reduction during microfiltration of yeast suspensions. Desalination 2009, 240, 46-53, https://doi.org/10.1016/j.desal.2008.02.025.

28. Zhang, N.; Nguyen, A. V.; Zhou, C. A review of the surface features and properties, surfactant adsorption and floatability of four key minerals of diasporic bauxite resources. Adv. Colloid Interface Sci. 2018, 254, 56-75, https://doi.org/10.1016/j.cis.2018.03.005.

29 Zhou, C.; Wang, Y. Structure-activity relationship of cationic surfactants as antimicrobial agents. Curr. Opin. Colloid Interface Sci 2020, 45, 28-43. https://doi.org/10.1016/j.cocis.2019.11.009.

30. Chenier, P.J. Surfactants, Soaps, and Detergents. In Survey of Industrial Chemistry; Springer US: Boston, MA, 2002; 461-474. https://doi.org/10.1007/978-1-4615-0603-4_24.

31. Rebello, S.; Asok, A.K.; Mundayoor, S.; Jisha, M.S. Surfactants: Toxicity, remediation and green surfactants. Environ. Chem. Lett. 2014, 12, 275-287, https://doi.org/10.1007/s10311-014-0466-2.

32. Surfactants market to grow at a CAGR of 7.3\%. Focus Surfactants 2019, 2019, 5, https://doi.org/10.1016/j.fos.2019.03.065.

33. Merghni, A.; Dallel, I.; Noumi, E.; Kadmi, Y.; Hentati, H.; Tobji, S.; Amor, A. B.; Mastouri, M. Antioxidant and antiproliferative potential of biosurfactants isolated from Lactobacillus casei and their anti-biofilm effect in oral Staphylococcus aureus strains. Microbial Pathogenesis 2017, https://doi.org/10.1016/j.micpath.2017.01.017.

34. Sambanthamoorthy, K.; Feng, X.; Patel, R.; Patel, S.; Paranavitana, C. Antimicrobial and antibiofilm potential of biosurfactants isolated from lactobacilli against multi-drug-resistant pathogens. BMC Microbiol. 2014, 14, 197, https://doi.org/10.1186/1471-2180-14-197.

35. De Araujo, L.V.; Freire, D.M.G.; Nitschke, M. Biossurfactantes: Propriedades anticorrosivas, antibiofilmes e antimicrobianas. Quim. Nova 2013, 36, 848-858, https://doi.org/10.1590/S0100-40422013000600019.

36. Gittens, J.E.; Smith, T.J.; Suleiman, R.; Akid, R. Current and emerging environmentally-friendly systems for fouling control in the marine environment. Biotechnol. Adv. 2013, 31, 1738-1753, https://doi.org/10.1016/j.biotechadv.2013.09.002.

37. Gule, N.P.; Begum, N.M.; Klumperman, B. Advances in biofouling mitigation: A review. Crit. Rev. Environ. Sci. Technol. 2016, 46, 535-555, https://doi.org/10.1080/10643389.2015.1114444.

38. Guo, S.; Lee, H.P.; Teo, S.L.M.; Khoo, B.C. Inhibition of barnacle cyprid settlement using low frequency and intensity ultrasound. Biofouling 2012, 28, 131-141, https://doi.org/10.1080/08927014.2012.658511.

39. Walker, M.E.; Safari, I.; Theregowda, R.B.; Hsieh, M.K.; Abbasian, J.; Arastoopour, H.; Dzombak, D.A.; Miller, D.C. Economic impact of condenser fouling in existing thermoelectric power plants. Energy 2012, 
44, 429-437, https://doi.org/10.1016/j.energy.2012.06.010.

40. Salta, M.; Wharton, J.A.; Blache, Y.; Stokes, K.R.; Briand, J.F. Marine biofilms on artificial surfaces: Structure and dynamics. Environ. Microbiol. 2013, 15, 2879-2893, https://doi.org/10.1111/14622920.12186

41. Wahl, M.; Goecke, F.; Labes, A.; Dobretsov, S.; Weinberger, F. The second skin: Ecological role of epibiotic biofilms on marine organisms. Front. Microbiol. 2012, 3, 1-21, https://doi.org/10.3389/fmicb.2012.00292.

42. Rajala, P.; Bomberg, M.; Huttunen-Saarivirta, E.; Priha, O.; Tausa, M.; Carpén, L. Influence of chlorination and choice of materials on fouling in cooling water system under brackish seawater conditions. Materials (Basel) 2016, 9, https://doi.org/10.3390/ma9060475.

43. Harding, J.L.; Reynolds, M.M. Combating medical device fouling. Trends Biotechnol. 2014, 32, 140-146, https://doi.org/10.1016/j.tibtech.2013.12.004.

44. Zhang, Y.; Fu, Q. Algal fouling of microfiltration and ultrafiltration membranes and control strategies: A review. Sep. Purif. Technol. 2018, 203, 193-208, https://doi.org/10.1016/j.seppur.2018.04.040.

45. Yusuf, Z.; Abdul Wahab, N.; Sahlan, S. Fouling control strategy for submerged membrane bioreactor filtration processes using aeration airflow, backwash, and relaxation: a review. Desalin. Water Treat. 2016, 57, 17683-17695, https://doi.org/10.1080/19443994.2015.1086893.

46. Bixler, G.D.; Bhushan, B. Biofouling: lessons from nature. Philos. Trans. R. Soc. A Math. Phys. Eng. Sci. 2012, 370, 2381-2417, https://doi.org/10.1098/rsta.2011.0502.

47. Sweat, L.H.; Swain, G.W.; Hunsucker, K.Z.; Johnson, K.B. Transported biofilms and their influence on subsequent macrofouling colonization. Biofouling 2017, 33, 433-449, https://doi.org/10.1080/08927014.2017.1320782.

48. Bachmann, R.T.; Edyvean, R.G.J. Biofouling: An historic and contemporary review of its causes, consequences and control in drinking water distribution systems. Biofilms 2005, 2, 197-227, https://doi.org/10.1017/S1479050506001979.

49. Greenhalgh, R.; Dempsey-Hibbert, N.C.; Whitehead, K.A. Antimicrobial strategies to reduce polymer biomaterial infections and their economic implications and considerations. Int. Biodeterior. Biodegrad. 2019, 136, 1-14, https://doi.org/10.1016/j.ibiod.2018.10.005.

50. Zhang, Z.; Wagner, V.E. Antimicrobial coatings and modifications on medical devices. Antimicrob. Coatings Modif. Med. Devices 2017, 1-273, https://doi.org/10.1007/978-3-319-57494-3.

51. Ludyansky, M.L. Algal fouling in cooling water systems. Biofouling 1991, 3, 13-21, https://doi.org/10.1080/08927019109378158.

52. Walker, M.E.; Safari, I.; Theregowda, R.B.; Hsieh, M.-K.; Abbasian, J.; Arastoopour, H.; Dzombak, D.A.; Miller, D.C. Economic impact of condenser fouling in existing thermoelectric power plants. Energy 2012, 44, 429-437, https://doi.org/10.1016/j.energy.2012.06.010.

53. Ibrahim, S.M.A.; Attia, S.I. The influence of condenser cooling seawater fouling on the thermal performance of a nuclear power plant. Ann. Nucl. Energy 2015, 76, 421-430, https://doi.org/10.1016/j.anucene.2014.10.018.

54. Fayomi, O.S.I.; Akande, I.G., Odigie, S. Economic Impact of Corrosion in Oil Sectors and Prevention: An Overview. J. Phys. Conf. Ser. 2019, 1378, 022037. https://doi.org/10.1088/1742-6596/1378/2/022037.

55. Zegans, M.E.; Toutain-Kidd, C.M., Gilmore, M.S. Bacterial Endophthalmitis Following Cataract Surgery, in: The Role of Biofilms in Device-Related Infections. Springer Berlin Heidelberg. 2008, Berlin, Heidelberg, 193-217. https://doi.org/10.1007/978-3-540-68119-9_8.

56. Flemming, H.-C., Geesey, G.G. Biofouling and Biocorrosion in Industrial Water Systems; Springer Berlin Heidelberg: Berlin, Heidelberg, 1991.

57. Abdul Azis, P.K.; Al-Tisan, I.; Sasikumar, N. Biofouling potential and environmental factors of seawater at a desalination plant intake. Desalination. 2001, 135, 69-82, https://doi.org/10.1016/S0011-9164(01)001400 .

58. Rahmani, K.; Jadidian, R.; Haghtalab, S. Evaluation of inhibitors and biocides on the corrosion, scaling and biofouling control of carbon steel and copper-nickel alloys in a power plant cooling water system. Desalination. 2015, 393, 174-185, https://doi.org/10.1016/j.desal.2015.07.026.

59. Bagge-Ravn, D.; Ng, Y.; Hjelm, M.; Christiansen, J.N.; Johansen, C.; Gram, L. The microbial ecology of processing equipment in different fish industries - analysis of the microflora during processing and following cleaning and disinfection. Int. J. Food Microbiol. 2003, 87, 239-250, https://doi.org/10.1016/S01681605(03)00067-9.

60. Galié, S.; García-Gutiérrez, C.; Miguélez, E.M.; Villar, C.J.; Lombó, F. Biofilms in the food industry: Health 
aspects and control methods. Front. Microbiol. 2018, 9, 1-18, https://doi.org/10.3389/fmicb.2018.00898.

61. Huang, K.; McLandsborough, L.A.; Goddard, J.M. Adhesion and removal kinetics of Bacillus cereus biofilms on Ni-PTFE modified stainless steel. Biofouling 2016, 32, 523-533, https://doi.org/10.1080/08927014.2016.1160284.

62. Liu, S.; Gunawan, C.; Barraud, N.; Rice, S.A.; Harry, E.J.; Amal, R. Understanding, Monitoring, and Controlling Biofilm Growth in Drinking Water Distribution Systems. Environ. Sci. Technol. 2016, 50, 89548976, https://doi.org/10.1021/acs.est.6b00835.

63. Flemming, H.-C. Biofouling and me: My Stockholm syndrome with biofilms. Water Res. 2020, $173,115576$. https://doi.org/10.1016/j.watres.2020.115576

64. Póvoa, A.A; Skinner, L.F.; de Araújo, F.V. Fouling organisms in marine litter (rafting on abiogenic substrates): A global review of literature. Mar. Pollut. Bull. 2021, 166, 112189. https://doi.org/10.1016/j.marpolbul.2021.112189.

65. Thouvenin, M.; Peron, J.J.; Langlois, V.; Guerin, P.; Langlois, J.Y.; Vallee-Rehel, K. Formulation and antifouling activity of marine paints: A study by a statistically based experiments plan. Prog. Org. Coatings. 2002, 44, 85-92, https://doi.org/10.1016/S0300-9440(01)00247-8.

66. Castro, Í.B.; Westphal, E.; Fillmann, G. Tintas Anti-Incrustantes de Terceira Geração: Novos Biocidas no Ambiente Aquático. Quim. Nova. 2011, 34, 1021-1031.

67. Maréchal, J.P.; Hellio, C. Challenges for the development of new non-toxic antifouling solutions. Int. J. Mol. Sci. 2009, 10, 4623-4637, https://doi.org/10.3390/ijms10114623.

68. Trepos, R.; Cervin, G.; Hellio, C.; Pavia, H.; Stensen, W.; Stensvåg, K.; Svendsen, J.-S.; Haug, T.; Svenson, J. Antifouling Compounds from the Sub-Arctic Ascidian Synoicum pulmonaria: Synoxazolidinones A and C, Pulmonarins A and B, and Synthetic Analogues. J. Nat. Prod. 2014, 77, 2105-2113, https://doi.org/10.1021/np5005032.

69. Rasulev, B.; Jabeen, F.; Stafslien, S.; Chisholm, B.J.; Bahr, J.; Ossowski, M.; Boudjouk, P. Polymer coating materials and their fouling release activity: A cheminformatics approach to predict properties. ACS Appl. Mater. Interfaces. 2017, 9, 1781-1792, https://doi.org/10.1021/acsami.6b12766.

70. Murthy, P.S.; Venkatesan, R. Industrial Biofilms and their Control. In Marine and Industrial Biofouling; Springer Berlin Heidelberg: Berlin, Heidelberg, 2009; 65-101.

71. Nguyen, T.; Roddick, F.; Fan, L. Biofouling of Water Treatment Membranes: A Review of the Underlying Causes, Monitoring Techniques and Control Measures. Membranes. 2012, 2, 804-840. https://doi.org/10.3390/membranes2040804.71

72. Venkatnarayanan, S.; Sriyutha Murthy, P.; Kirubagaran, R.; Venugopalan, V.P. Chlorine dioxide as an alternative antifouling biocide for cooling water systems: Toxicity to larval barnacle Amphibalanus reticulatus (Utinomi). Mar. Pollut. Bull. 2017, https://doi.org/10.1016/j.marpolbul.2017.01.023.

73. Dave, N.; Joshi, T. A Concise Review on Surfactants and Its Significance. Int. J. Appl. Chem. 2017, 13, 663672.

74. Holmberg, K. Interactions between surfactants and hydrolytic enzymes. Colloids Surfaces B Biointerfaces 2018, 168, 169-177, https://doi.org/10.1016/j.colsurfb.2017.12.002.

75. Yunfei, H.; Yazhuo, S.; Honglai, L.; Dominique, L.; Anniina, S. Surfactant Adsorption onto Interfaces: Measuring the Surface Excess in Time. Langmuir 2012, 28, 3146-3151, https://doi.org/10.1021/la2047454.

76. Singh, A.; Van Hamme, J.D.; Ward, O.P. Surfactants in microbiology and biotechnology: Part 2. Application aspects. Biotechnol. Adv. 2007, 25, 99-121, https://doi.org/10.1016/j.biotechadv.2006.10.004.

77. Jahan, R.; Bodratti, A.M.; Tsianou, M.; Alexandridis, P. Biosurfactants, natural alternatives to synthetic surfactants: Physicochemical properties and applications. Adv. Colloid Interface Sci. 2020, 275, 102061, https://doi.org/10.1016/j.cis.2019.102061.

78. Otzen, D.E. Biosurfactants and surfactants interacting with membranes and proteins: Same but different? Biochim. Biophys. Acta - Biomembr. 2017, 1859, 639-649, https://doi.org/10.1016/j.bbamem.2016.09.024.

79. Chew, N.G.P.; Zhao, S.; Loh, C.H.; Permogorov, N.; Wang, R. Surfactant effects on water recovery from produced water via direct-contact membrane distillation. J. Memb. Sci. 2017, 528, 126-134, https://doi.org/10.1016/j.memsci.2017.01.024.

80. De Almeida, D.G.; Soares Da Silva, R. de C.F.; Luna, J.M.; Rufino, R.D.; Santos, V.A.; Banat, I.M.; Sarubbo, L.A. Biosurfactants: Promising Molecules for Petroleum Biotechnology Advances. Front. Microbiol. 2016, 7, 1-14, https://doi.org/10.3389/fmicb.2016.01718.

81. Varjani, S.J.; Upasani, V.N. Critical review on biosurfactant analysis, purification and characterization using rhamnolipid as a model biosurfactant. Bioresour. Technol. 2017, 232, 389-397, 
https://doi.org/10.1016/J.BIORTECH.2017.02.047.

82. Jirku, V.; Cejkova, A.; Schreiberova, O.; Jezdik, R.; Masak, J. Multicomponent biosurfactants - A "Green Toolbox" extension. $\quad$ Biotechnol. Adv. 2015, 33, https://doi.org/10.1016/j.biotechadv.2015.03.005.

83. Barra Caracciolo, A.; Cardoni, M.; Pescatore, T.; Patrolecco, L. Characteristics and environmental fate of the anionic surfactant sodium lauryl ether sulphate (SLES) used as the main component in foaming agents for mechanized tunnelling. $\quad$ Environ. Pollut. https://doi.org/10.1016/J.ENVPOL.2017.04.008.

84. Pereira, M.O. Machado, I. Simoes, M.V.M. Preventing biofilm formation using surfactants. Biofilm Club 2007, 167-174.

85. Percival, S.L.; Mayer, D.; Malone, M.; Swanson, T.; Gibson, D.; Schultz, G. Surfactants and their role in wound cleansing and biofilm management. J. Wound Care 2017, 26, 680-690, https://doi.org/10.12968/jowc.2017.26.11.680.

86. Bezerra, K.G.O.; Rufino, R.D.; Luna, J.M.; Sarubbo, L.A. Saponins and microbial biosurfactants: Potential raw materials for the formulation of cosmetics. Biotechnol. Prog. 2018, https://doi.org/10.1002/btpr.2682.

87. Perfumo, A.; Banat, I.M.; Marchant, R. Going Green and Cold: Biosurfactants from Low-Temperature Environments to Biotechnology Applications. Trends Biotechnol. 2018, 36, 277-289. https://doi.org/10.1016/j.tibtech.2017.10.016

88. Seo, Y.; Bishop, P.L. Influence of Nonionic Surfactant on Attached Biofilm Formation and Phenanthrene Bioavailability during Simulated Surfactant Enhanced Bioremediation. Environ. Sci. Technol. 2007, 41, 7107-7113, https://doi.org/10.1021/es0701154.

89. Buckingham-Meyer, K.; Goeres, D.M.; Hamilton, M.A. Comparative evaluation of biofilm disinfectant efficacy tests. J. Microbiol. Methods 2007, 70, 236-244, https://doi.org/10.1016/j.mimet.2007.04.010.

90. Whitekettle, W.K. Effects of surface-active chemicals on microbial adhesion. J. Ind. Microbiol. 1991, 7, 105116, https://doi.org/10.1007/BF01576072.

91. Van Hamme, J.D.; Singh, A.; Ward, O.P. Physiological aspects. Part 1 in a series of papers devoted to surfactants in microbiology and biotechnology. Biotechnol. Adv. 2006, 24, 604-620, https://doi.org/10.1016/j.biotechadv.2006.08.001.

92. Olkowska, E.; Polkowska, Z.; Namieśnik, J. Analytics of surfactants in the environment: Problems and challenges. Chem. Rev. 2011, 111, 5667-5700, https://doi.org/10.1021/cr100107g.

93. Kogawa, A.C.; Cernic, B.G.; do Couto, L.G.D.; Salgado, H.R.N. Synthetic detergents: 100 years of history. Saudi Pharm. J. 2017, 25, 934-938, https://doi.org/10.1016/j.jsps.2017.02.006.

94. Glomski, L. Zebra Mussel Chemical Control Guide, Version 2.0; 2015.

95. Simões, M.; Simões, L.C.; Machado, I.; Pereira, M.O.; Vieira, M.J. Control of flow-generated biofilms with surfactants: Evidence of resistance and recovery. Food Bioprod. Process. 2006, 84, 338-345, https://doi.org/10.1205/fbp06022.

96. Sun, W.; Wang, Y.; Zhang, W.; Ying, H.; Wang, P. Novel surfactant peptide for removal of biofilms. Colloids Surfaces B Biointerfaces 2018, 172, 180-186, https://doi.org/10.1016/j.colsurfb.2018.08.029.

97. Santos, D.; Rufino, R.; Luna, J.; Santos, V.; Sarubbo, L. Biosurfactants: Multifunctional Biomolecules of the 21st Century. Int. J. Mol. Sci. 2016, 17, 401, https://doi.org/10.3390/ijms17030401.

98. Sivapathasekaran, C.; Sen, R. Origin, properties, production and purification of microbial surfactants as molecules with immense commercial potential. Tenside, Surfactants, Deterg. 2017, 54, 92-104.

99. Geetha, S.J.; Banat, I.M.; Joshi, S.J. Biosurfactants: Production and potential applications in microbial enhanced oil recovery (MEOR). Biocatal. Agric. Biotechnol. 2018, 14, 23-32, https://doi.org/10.1016/j.bcab.2018.01.010.

100.Hausmann, R.; Syldatk, C. Types and Classification of Microbial Surfactants. Biosurfactants 2014, 3-18, https://doi.org/10.1201/b17599-3.

101.Moya, F.; Maturana, A. Animal-Derived Surfactants Versus Past and Current Synthetic Surfactants: Current Status. Clin. Perinatol. 2007, 34, 145-177, https://doi.org/10.1016/J.CLP.2006.12.005.

102.Ndlovu, T.; Rautenbach, M.; Vosloo, J.A.; Khan, S.; Khan, W. Characterisation and antimicrobial activity of biosurfactant extracts produced by Bacillus amyloliquefaciens and Pseudomonas aeruginosa isolated from a wastewater treatment plant. AMB Express 2017, 7, https://doi.org/10.1186/s13568-017-0363-8.

103.Edwards, K.R.; Lepo, J.E.; Lewis, M.A. Toxicity comparison of biosurfactants and synthetic surfactants used in oil spill remediation to two estuarine species. Mar. Pollut. Bull. 2003, 46, 1309-1316, https://doi.org/10.1016/S0025-326X(03)00238-8. 
104.Zdziennicka, A.; Jańczuk, B. Wetting and adhesion properties of rhamnolipid and surfactin. Int. J. Adhes. Adhes. 2018, 84, 275-282, https://doi.org/10.1016/j.ijadhadh.2018.04.005.

105.Rocha e Silva, N.M.P.; Meira, H.M.; Almeida, F.C.G.; Soares da Silva, R. de C.F.; Almeida, D.G.; Luna, J.M.; Rufino, R.D.; Santos, V.A.; Sarubbo, L.A. Natural Surfactants and Their Applications for Heavy Oil Removal in Industry. Sep. Purif. Rev. 2019, 48, 267-281, https://doi.org/10.1080/15422119.2018.1474477.

106.Zhu, Z.; Wen, Y.; Yi, J.; Cao, Y.; Liu, F.; McClements, D.J. Comparison of natural and synthetic surfactants at forming and stabilizing nanoemulsions: Tea saponin, Quillaja saponin, and Tween 80. J. Colloid Interface Sci. 2019, 536, 80-87, https://doi.org/10.1016/j.jcis.2018.10.024.

107.Nitschke, M.; Silva, S.S. e. Recent food applications of microbial surfactants. Crit. Rev. Food Sci. Nutr. 2018, 58, 631-638, https://doi.org/10.1080/10408398.2016.1208635.

108.Abdelli, F.; Jardak, M.; Elloumi, J.; Stien, D.; Cherif, S.; Mnif, S.; Aifa, S. Antibacterial, anti-adherent and cytotoxic activities of surfactin(s) from a lipolytic strain Bacillus safensis F4. Biodegradation 2019, 30, 287300, https://doi.org/10.1007/s10532-018-09865-4.

109.Jimoh, A.A.; Lin, J. Biosurfactant: A new frontier for greener technology and environmental sustainability. Ecotoxicol. Environ. Saf. 2019, 184, 109607, https://doi.org/10.1016/j.ecoenv.2019.109607.

110.Liu, K.; Sun, Y.; Cao, M.; Wang, J.; Lu, J.R.; Xu, H. Rational design, properties, and applications of biosurfactants: a short review of recent advances. Curr. Opin. Colloid Interface Sci. 2020, 45, 57-67, https://doi.org/10.1016/j.cocis.2019.12.005.

111.Araujo, L.V. de; Guimarães, C.R.; Marquita, R.L. da S.; Santiago, V.M.J.; de Souza, M.P.; Nitschke, M.; Freire, D.M.G. Rhamnolipid and surfactin: Anti-adhesion/antibiofilm and antimicrobial effects. Food Control 2016, 63, 171-178, https://doi.org/10.1016/j.foodcont.2015.11.036.

112.Ong, S.A.; Wu, J.C. A simple method for rapid screening of biosurfactant-producing strains using Bromothymol blue alone. Biocatal. Agric. Biotechnol. 2018, 16, 121-125, https://doi.org/10.1016/J.BCAB.2018.07.027.

113.Cheok, C.Y.; Salman, H.A.K.; Sulaiman, R. Extraction and quantification of saponins: A review. Food Res. Int. 2014, 59, 16-40, https://doi.org/10.1016/j.foodres.2014.01.057.

114.Liu, J. Recent Advances in the Isolation, Synthesis and Biological Activity of Marine Guanidine Alkaloids. Mar. drugs 2017, 1-19, https://doi.org/10.3390/md15100324.

115.Ramanathan, R. Animal-derived surfactants: where are we? The evidence from randomized, controlled clinical trials. J. Perinatol. 2009, 29, S38-S43, https://doi.org/10.1038/jp.2009.31.

116.Sałek, K.; Euston, S.R. Sustainable microbial biosurfactants and bioemulsifiers for commercial exploitation. Process Biochem. 2019, 85, 143-155, https://doi.org/10.1016/j.procbio.2019.06.027.

117.Drakontis, C.E.; Amin, S. Biosurfactants: Formulations, properties, and applications. Curr. Opin. Colloid Interface Sci. 2020, 48, 77-90, https://doi.org/10.1016/j.cocis.2020.03.013.

118.Chong, H.; Li, Q. Microbial production of rhamnolipids: Opportunities, challenges and strategies. Microb. Cell Fact. 2017, 16, 1-12, https://doi.org/10.1186/s12934-017-0753-2.

119.Lovaglio, R.B.; Silva, V.L.; Ferreira, H.; Hausmann, R.; Contiero, J. Rhamnolipids know-how: Looking for strategies for its industrial dissemination. Biotechnol. Adv. 2015, 33, 1715-1726, https://doi.org/10.1016/j.biotechadv.2015.09.002.

120.Henkel, M.; Müller, M.M.; Kügler, J.H.; Lovaglio, R.B.; Contiero, J.; Syldatk, C.; Hausmann, R. Rhamnolipids as biosurfactants from renewable resources: Concepts for next-generation rhamnolipid production. Process Biochem. 2012, 47, 1207-1219, https://doi.org/10.1016/j.procbio.2012.04.018.

121.Satpute, S.K.; Płaza, G.A.; Banpurkar, A.G. Biosurfactants’ Production from Renewable Natural Resources: Example of Innovativeand Smart Technology in Circular Bioeconomy. Manag. Syst. Prod. Eng. 2017, 25, https://doi.org/10.1515/mspe-2017-0007.

122.Claus, S.; Van Bogaert, I.N.A. Sophorolipid production by yeasts: a critical review of the literature and suggestions for future research. Appl. Microbiol. Biotechnol. 2017, 101, 7811-7821, https://doi.org/10.1007/s00253-017-8519-7.

123.Inès, M.; Dhouha, G. Lipopeptide surfactants: Production, recovery and pore forming capacity. Peptides 2015, 71, 100-112, https://doi.org/10.1016/j.peptides.2015.07.006.

124.Zhao, H.; Shao, D.; Jiang, C.; Shi, J.; Li, Q.; Huang, Q.; Rajoka, M.S.R.; Yang, H.; Jin, M. Biological activity of lipopeptides from Bacillus. Appl. Microbiol. Biotechnol. 2017, 101, 5951-5960, https://doi.org/10.1007/s00253-017-8396-0.

125.Kuyukina, M.S.; Ivshina, I.B.; Korshunova, I.O.; Stukova, G.I.; Krivoruchko, A.V. Diverse effects of a biosurfactant from Rhodococcus ruber IEGM 231 on the adhesion of resting and growing bacteria to 
polystyrene. AMB Express 2016, 6, https://doi.org/10.1186/s13568-016-0186-z.

126.Shakeri, F.; Babavalian, H.; Amoozegar, M.A.; Ahmadzadeh, Z.; Zuhuriyanizadi, S.; Afsharian, M.P. Production and application of biosurfactants in biotechnology. Biointerf. Res. Appl. Chem. 2021, 11, 10446 - 10460, https://doi.org/10.33263/BRIAC113.1044610460.

127.Nikolova, C.; Gutierrez, T. Biosurfactants and their applications in the oil and gas industry: current state of knowledge and future perspectives. Frontiers Bioeng. Botechnol. 2021, 9, 626639, https://doi.org/10.3389/fbioe.2021.626639.

128.Rawat, G.; Dhasmana, A.; Kumar, V. Biosurfactants: the next generation biomolecules for diverse applications. Environ. Sustainability 2020, 3, 353-369, https://doi.org/10.1007/s42398-020-00128-8.

129.Krasowska, A.; Sigler, K. How microorganisms use hydrophobicity and what does this mean for human needs? Front. Cell. Infect. Microbiol. 2014, 4, 112, https://doi.org/10.3389/fcimb.2014.00112.

130.Liao, C.; Liang, X.; Soupir, M.L.; Jarboe, L.R. Cellular, particle and environmental parameters influencing attachment in surface waters: A review. J. Appl. Microbiol. 2015, 119, 315-330, https://doi.org/10.1111/jam.12860.

131.Ostroumov, S.A.; Widdows, J. Inhibition of mussel suspension feeding by surfactants of three classes. Hydrobiologia 2006, 556, 381-386, https://doi.org/10.1007/s10750-005-1200-7.

132.Invally, K.; Ju, L.-K. Biolytic Effect of Rhamnolipid Biosurfactant and Dodecyl Sulfate Against Phagotrophic Alga Ochromonas danica. J. Surfactants Deterg. 2017, https://doi.org/10.1007/s11743-017-2005-1.

133.Silva, M. da G.C da., Durval, I.J.B., da Silva, M.E.P., Sarubbo, L.A. Potential Applications of Anti-Adhesive Biosurfactants, in: Inamuddin, Ahamed, M.I., Prasad, R. (Eds.), Microbial Biosurfactants Preparation, Properties and Applications. Springer Nature Singapore. 2021. Singapure, 213-225. https://doi.org/10.1007/978-981-15-6607-3_10.

134.Díaz De Rienzo, M.A.; Banat, I.M.; Dolman, B.; Winterburn, J.; Martin, P.J. Sophorolipid biosurfactants: Possible uses as antibacterial and antibiofilm agent. N. Biotechnol. 2015, 32, 720-726, https://doi.org/10.1016/j.nbt.2015.02.009.

135.Inès, M.; Dhouha, G. Glycolipid biosurfactants: Potential related biomedical and biotechnological applications. Carbohydr. Res. 2015, 416, 59-69, https://doi.org/10.1016/j.carres.2015.07.016.

136.Płaza, G.; Achal, V. Biosurfactants: Eco-friendly and innovative biocides against biocorrosion. Int. J. Mol. Sci. 2020, 21, https://doi.org/10.3390/ijms21062152.

137.Roy, R.; Tiwari, M.; Donelli, G.; Tiwari, V. Strategies for combating bacterial biofilms: A focus on antibiofilm agents and their mechanisms of action. Virulence 2018, 9, 522-554, https://doi.org/10.1080/21505594.2017.1313372.

138.Khalid, H.F.; Tehseen, B.; Sarwar, Y.; Hussain, S.Z.; Khan, W.S.; Raza, Z.A.; Bajwa, S.Z.; Kanaras, A.G.; Hussain, I.; Rehman, A. Biosurfactant coated silver and iron oxide nanoparticles with enhanced anti-biofilm and anti-adhesive properties. J. Hazard. Mater. 2019, 364, 441-448, https://doi.org/10.1016/j.jhazmat.2018.10.049.

139.Gowrishankar, S.; Kamaladevi, A.; Sorimuthu Ayyanar, K.; Balamurugan, K.; Karutha Pandian, S. Bacillus amyloliquefaciens-secreted cyclic dipeptide- cyclo(L-leucyl- L-prolyl) inhibits biofilm and virulence in methicillin-resistant Staphylococcus aureus. RSC Adv. 2015, 5, 95788-95804, https://doi.org/10.1039/C5RA11641D.

140.Nalini, S.; Parthasarathi, R. Production and characterization of rhamnolipids produced by Serratia rubidaea SNAU02 under solid-state fermentation and its application as biocontrol agent. Bioresour. Technol. 2014, 173, 231-238, https://doi.org/10.1016/j.biortech.2014.09.051.

141.Feroz, B. Saponins from Marine Macroalgae: A Review. J. Mar. Sci. Res. Dev. 2018, 08, 1-8, https://doi.org/10.4172/2155-9910.1000255.

142.Xiao, G.; Shao, X.; Zhu, D.; Yu, B. Chemical synthesis of marine saponins. Nat. Prod. Rep. 2019, 36, 769787, https://doi.org/10.1039/c8np00087e.

143.Francis, G.; Kerem, Z.; Makkar, H.P.S.; Becker, K. The biological action of saponins in animal systems: a review. Br. J. Nutr. 2002, 88, 587-605, https://doi.org/10.1079/bjn2002725.

144.Liu, Z.; Li, Z.; Zhong, H.; Zeng, G.; Liang, Y.; Chen, M.; Wu, Z.; Zhou, Y.; Yu, M.; Shao, B. Recent advances in the environmental applications of biosurfactant saponins: A review. J. Environ. Chem. Eng. 2017, 5, 60306038, https://doi.org/10.1016/J.JECE.2017.11.021.

145.Sarwar, A.; Hassan, M.N.; Imran, M.; Iqbal, M.; Majeed, S.; Brader, G.; Sessitsch, A.; Hafeez, F.Y. Biocontrol activity of surfactin A purified from Bacillus NH-100 and NH-217 against rice bakanae disease. Microbiol. Res. 2018, 209, 1-13, https://doi.org/10.1016/j.micres.2018.01.006. 
146.Timmis, K.N. Environmental Biotechnology Vol. 2; Gothandam, K.M., Ranjan, S., Dasgupta, N., Lichtfouse, E., Eds.; Environmental Chemistry for a Sustainable World; Springer International Publishing: Cham, 2020; 45.

147.Santos, V.L.; Nardi Drummond, R.M.; Dias-Souza, M.V. Biosurfactants as Antimicrobial and Antibiofilm Agents. In Current Developments in Biotechnology and Bioengineering; Elsevier, 2017; 371-402, https://doi.org/10.1016/B978-0-444-63660-7.00015-2.

148.Gudiña, E.J.; Fernandes, E.C.; Teixeira, J.A.; Rodrigues, L.R. Antimicrobial and anti-adhesive activities of cell-bound biosurfactant from Lactobacillus agilis CCUG31450. RSC Adv. 2015, 5, 90960-90968, https://doi.org/10.1039/C5RA11659G.

149.Gudiña, E.J.; Rocha, V.; Teixeira, J.A.; Rodrigues, L.R. Antimicrobial and antiadhesive properties of a biosurfactant isolated from Lactobacillus paracasei ssp. paracasei A20. Lett. Appl. Microbiol. 2010, 50, 419424, https://doi.org/10.1111/j.1472-765X.2010.02818.X.

150.Yan, X.; Gu, S.; Cui, X.; Shi, Y.; Wen, S.; Chen, H.; Ge, J. Antimicrobial, anti-adhesive and anti-biofilm potential of biosurfactants isolated from Pediococcus acidilactici and Lactobacillus plantarum against Staphylococcus aureus CMCC26003. Microb. Pathog. 2019, 127, 12-20, https://doi.org/10.1016/j.micpath.2018.11.039.

151.Shu, Q.; Wei, T.; Lu, H.; Niu, Y.; Chen, Q. Mannosylerythritol lipids: dual inhibitory modes against Staphylococcus aureus through membrane-mediated apoptosis and biofilm disruption. Appl. Microbiol. Biotechnol. 2020, 104, 5053-5064, https://doi.org/10.1007/s00253-020-10561-8.

152.Ohadi, M.; Shahravan, A.; Dehghannoudeh, N.; Eslaminejad, T.; Banat, I.M.; Dehghannoudeh, G. Potential use of microbial surfactant in microemulsion drug delivery system: A systematic review. Drug Des. Devel. Ther. 2020, 14, 541-550, https://doi.org/10.2147/DDDT.S232325.

153.Giri, S.S.; Ryu, E.; Sukumaran, V.; Park, S.C. Antioxidant, antibacterial, and anti-adhesive activities of biosurfactants isolated from Bacillus strains. Microb. Pathog. 2019, 132, 66-72, https://doi.org/10.1016/j.micpath.2019.04.035.

154.Kayanadath, S.; Nathan, V.K.; Ammini, P. Anti-Biofilm Activity of Biosurfactant Derived from Halomonas sp., a Lipolytic Marine Bacterium from the Bay of Bengal. Microbiol. (Russian Fed. 2019, 88, 585-599, https://doi.org/10.1134/S0026261719050072.

155.Vecino, X.; Rodríguez-López, L.; Ferreira, D.; Cruz, J.M.; Moldes, A.B.; Rodrigues, L.R. Model Bioactivity of glycolipopeptide cell-bound biosurfactants against skin pathogens. Int. J. Biol. Macromol. 2018, 109, https://doi.org/10.1016/j.ijbiomac.2017.11.088.

156.Elshikh, M.; Funston, S.; Chebbi, A.; Ahmed, S.; Marchant, R.; Banat, I.M. Rhamnolipids from nonpathogenic Burkholderia thailandensis E264: Physicochemical characterization, antimicrobial and antibiofilm efficacy against oral hygiene related pathogens. N. Biotechnol. 2017, 36, 26-36, https://doi.org/10.1016/j.nbt.2016.12.009.

157.Rienzo, M.A.D. De; Banat, I.M.; Dolman, B.; Winterburn, J.; Martin, P.J. Sophorolipid biosurfactants: Possible uses as antibacterial and antibiofilm agent. N. Biotechnol. 2015, 32, 720-726, https://doi.org/10.1016/j.nbt.2015.02.009.

158.Sabaté, D.C.; Audisio, M.C. Inhibitory activity of surfactin, produced by different Bacillus subtilis subsp. subtilis strains, against Listeria monocytogenes sensitive and bacteriocin-resistant strains. Microbiol. Res. 2013, 168, 125-129, https://doi.org/10.1016/j.micres.2012.11.004.

159.Gomes, M.Z. do V.; Nitschke, M. Evaluation of rhamnolipid and surfactin to reduce the adhesion and remove biofilms of individual and mixed cultures of food pathogenic bacteria. Food Control 2012, 25, 441-447, https://doi.org/10.1016/j.foodcont.2011.11.025.

160.Vieira De Araujo, L.; Abreu, F.; Lins, U.; Maria De Melo, L.; Anna, S.; Nitschke, M.; Maria, D.; Freire, G. Rhamnolipid and surfactin inhibit Listeria monocytogenes adhesion. FRIN 2011, 44, 481-488, https://doi.org/10.1016/j.foodres.2010.09.002.

161.Monteiro, A.S.; Miranda, T.T.; Lula, I.; Denadai, Â.M.L.; Sinisterra, R.D.; Santoro, M.M.; Santos, V.L. Inhibition of Candida albicans CC biofilms formation in polystyrene plate surfaces by biosurfactant produced by Trichosporon montevideense CLOA72. Colloids Surfaces B: Biointerfaces 2011, 84, 467-476, https://doi.org/10.1016/j.colsurfb.2011.02.001.

162.Rufino, R.D.; Luna, J.M.; Sarubbo, L.A.; Rodrigues, L.R.M.; Teixeira, J.A.C.; Campos-Takaki, G.M. Antimicrobial and anti-adhesive potential of a biosurfactant Rufisan produced by Candida lipolytica UCP 0988. Colloids Surfaces B Biointerfaces. 2011, 84, 1-5, https://doi.org/10.1016/j.colsurfb.2010.10.045.

163.Luna, J.M.; Rufino, R.D.; Sarubbo, L.A.; Rodrigues, L.R.M.; Teixeira, J.A.C.; de Campos-Takaki, G.M. 
Evaluation Antimicrobial and Antiadhesive Properties of the Biosurfactant Lunasan Produced by Candida sphaerica UCP 0995. Curr. Microbiol. 2011, 62, 1527-1534, https://doi.org/10.1007/s00284-011-9889-1.

164.Dusane, D.H.; Pawar, V.S.; Nancharaiah, Y. V.; Venugopalan, V.P.; Kumar, A.R.; Zinjarde, S.S. Anti-biofilm potential of a glycolipid surfactant produced by a tropical marine strain of Serratia marcescens. Biofouling. 2011, 27, 645-654, https://doi.org/10.1080/08927014.2011.594883.

165.Dusane, D.H.; Nancharaiah, Y.V.; Zinjarde, S.S.; Venugopalan, V.P. Rhamnolipid mediated disruption of marine Bacillus pumilus biofilms. Colloids Surfaces B: Biointerfaces 2010, 81, 242-248, https://doi.org/10.1016/j.colsurfb.2010.07.013.

166.Nitschke, M.; Araújo, L.V.; Costa, S.G.V.A.O.; Pires, R.C.; Zeraik, A.E.; Fernandes, A.C.L.B.; Freire, D.M.G.; Contiero, J. Surfactin reduces the adhesion of food-borne pathogenic bacteria to solid surfaces. Lett. Appl. Microbiol. 2009, 49, 241-247, https://doi.org/10.1111/j.1472-765X.2009.02646.x.

167.Cao, X.-H.; Liao, Z.-Y.; Wang, C.-L.; Yang, W.-Y.; Lu, M.-F. Evaluation of a Lipopeptide Biosurfactant From Bacillus Natto Tk-1 As a Potential Source of Anti-Adhesive, Antimicrobial and Antitumor Activities. Brazilian J. Microbiol. 2009, 40, 373-379.

168.Das, P.; Mukherjee, S.; Sen, R. Antiadhesive action of a marine microbial surfactant. Colloids Surfaces B Biointerfaces 2009, 71, 183-186, https://doi.org/10.1016/j.colsurfb.2009.02.004.

169.Davey, M.E.; Caiazza, N.C.; O’Toole, G.A. Rhamnolipid surfactant production affects biofilm architecture in Pseudomonas aeruginosa PAO1. J. Bacteriol. 2003, 185, 1027-1036, https://doi.org/10.1128/jb.185.3.1027-1036.2003.

170.Olasanmi, I.O.; Thring, R.W. The role of biosurfactants in the continued drive for environmental sustainability. Sustain. 2018, 10, 1-12, https://doi.org/10.3390/su10124817.

171.Chen, J.; Wu, Q.; Hua, Y.; Chen, J.; Zhang, H.; Wang, H. Potential applications of biosurfactant rhamnolipids in agriculture and biomedicine. Appl. Microbiol. Biotechnol. 2017, 101, 8309-8319, https://doi.org/10.1007/s00253-017-8554-4.

172.Mulligan, C.N. Sustainable Remediation of Contaminated Soil Using Biosurfactants. Front. Bioeng. Biotechnol. 2021. https://doi.org/10.3389/fbioe.2021.635196.

173.Lima, T.M.S.; Procópio, L.C.; Brandão, F.D.; Carvalho, A.M.X.; Tótola, M.R.; Borges, A.C. Biodegradability of bacterial surfactants. Biodegradation 2011, 22, 585-592, https://doi.org/10.1007/s10532010-9431-3.

174.Hogan, D.E.; Tian, F.; Malm, S.W.; Olivares, C.; Palos Pacheco, R.; Simonich, M.T.; Hunjan, A.S.; Tanguay, R.L.; Klimecki, W.T.; Polt, R.; Pemberton, J.E.; Curry, J.E.; Maier, R.M. Biodegradability and toxicity of monorhamnolipid biosurfactant diastereomers. J. Hazard. Mater. 2019, 364, 600-607, https://doi.org/10.1016/j.jhazmat.2018.10.050.

175.De Oliveira, D.W.F.; Cara, A.B.; Lechuga-Villena, M.; García-Román, M.; Melo, V.M.M.; Gonçalves, L.R.B.; Vaz, D.A. Aquatic toxicity and biodegradability of a surfactant produced by Bacillus subtilis ICA56. J. Environ. Sci. Heal. Part A 2017, 52, 174-181, https://doi.org/10.1080/10934529.2016.1240491.

176.Landoulsi, J.; Cooksey, K.E.; Dupres, V. Review - Interactions between diatoms and stainless steel : focus on biofouling and biocorrosion. 2017, 27, https://doi.org/10.1080/08927014.2011.629043.

177.Korenblum, E.; Regina de Vasconcelos Goulart, F.; de Almeida Rodrigues, I.; Abreu, F.; Lins, U.; Alves, P.B.; Blank, A.F.; Valoni, E.; Sebastián, G. V; Alviano, D.S.; Alviano, C.S.; Seldin, L. Antimicrobial action and anticorrosion effect against sulfate reducing bacteria by lemongrass (Cymbopogon citratus) essential oil and its major component, the citral. AMB Express 2013, 3, 44, https://doi.org/10.1186/2191-0855-3-44.

178.Malik, M.A.; Hashim, M.A.; Nabi, F.; AL-Thabaiti, S.A.; Khan, Z. Anti-corrosion ability of surfactants: A review. Int. J. Electrochem. Sci. 2011, 6, 1927-1948.

179.Zin, I.M.; Pokhmurskii, V.I.; Korniy, S.A.; Karpenko, O. V.; Lyon, S.B.; Khlopyk, O.P.; Tymus, M.B. Corrosion inhibition of aluminium alloy by rhamnolipid biosurfactant derived from pseudomonas sp. PS-17. Anticorrosion Methods Mater. 2018, 65, 517-527, https://doi.org/10.1108/ACMM-03-2017-1775.

180.Grasland, B.; Mitalane, J.; Briandet, R.; Quemener, E.; Meylheuc, T.; Linossier, I.; Vallee-Rehel, K.; Haras, D. Bacterial biofilm in seawater: cell surface properties of early-attached marine bacteria. Biofouling. 2003, 19, 307-313, https://doi.org/10.1080/0892701031000121041.

181.Nickzad, A.; Déziel, E. The involvement of rhamnolipids in microbial cell adhesion and biofilm development - an approach for control? Lett. Appl. Microbiol. 2014, 58, 447-453, https://doi.org/10.1111/lam.12211.

182.Padmavathi, A.R.; Pandian, S.K. Antibiofilm activity of biosurfactant producing coral associated bacteria isolated from gulf of mannar. Indian J. Microbiol. 2014, 54, 376-82, https://doi.org/10.1007/s12088-0140474-8. 
183.Silva, M.D.G.C.; Almeida, D.G.; Soares da Silva, R.D.C.F.; Meira, H.M.; Almeida, F.G.; Fernandes, M.L.B.; Silva, A.K.P.; Santos, V.A.; Sarubbo, L.A. Chemically modified natural substances screening for biofilms inhibition and biofouling control. Chem. Eng. Trans. 2018, 64, https://doi.org/10.3303/CET1864110.

184.Song, B.; Wang, Y. zhen; Wang, G. yuan; Liu, G.L.; Li, W. zhong; Yan, F. The lipopeptide 6-2 produced by Bacillus amyloliquefaciens anti-CA has potent activity against the biofilm-forming organisms. Mar. Pollut. Bull. 2016, 108, 62-69, https://doi.org/10.1016/j.marpolbul.2016.04.062.

185.Singh, A.K.; Sharma, P. Disinfectant-like activity of lipopeptide biosurfactant produced by Bacillus tequilensis strain SDS21. Colloids Surfaces $B \quad$ Biointerfaces $2020, \quad 185, \quad 110514$, https://doi.org/10.1016/j.colsurfb.2019.110514.

186.Soroldoni, S.; Abreu, F.; Castro, Í.B.; Duarte, F.A.; Pinho, G.L.L. Are antifouling paint particles a continuous source of toxic chemicals to the marine environment? J. Hazard. Mater. 2017, 330, 76-82, https://doi.org/10.1016/j.jhazmat.2017.02.001.

187.Mnif, I.; Ghribi, D. Glycolipid biosurfactants: main properties and potential applications in agriculture and food industry. J. Sci. Food Agric. 2016, 96, 4310-4320, https://doi.org/10.1002/jsfa.7759.

188.Farias, C.B.B.; Almeida, F.C.G.; Silva, I.A.; Souza, T.C.; Meira, H.M.; Soares da Silva, R.C.F.; Luna, J.M.; Santos, V.A.; Converti, A.; Banat, I.M.; Sarubbo, L.A. Green surfactants: Industrial production and market prospects. Electr. J. of Biotechnol. 2021, 51, 28-39, https://doi.org/10.1016/j.ejbt.2021.02.002.

189.Durval, I.J.B.; Rufino, R.D.; Sarubbo, L.A. Biosurfactant as an environmental remediation agent: toxicity, formulation and application in the removal of petroderivate in sand and rock walls. Biointerf. Res. Appl. Chem., 2022, 12, 34-48, https://doi.org/10.33263/BRIAC121.034048.

190.Tapia, D.; Alejandro, M.; Herrera, O.; Ricardo, J.; Quiroga, I.; Jimena, C. Strain of Cobetia marina and biosurfactant extract obtained from same 2014. EP2716749A1, 2014.

191.Sadasivan, L. Aqueous coatings and paints incorporating one or more antimicrobial biosurfactants and methods for using same 2013. US20130296461A1, 2013.

192.Ceri, H.; J. Turner, R.; Martinotti, M.G.; Rivardo, F.; Allegrone, G. Biosurfactant composition produced by a new Bacillus licheniforms strain, uses and products thereof 2013. US8377455B2, 2013.

193.Shuhua, Q.; Xiaoyong, Z.; Jiang, P. Methylotrophic bacillus for producing surfactins and iturin A compounds and application of methylotrophic bacillus 2014. CN102994418B, 2014.

194.Contos, M.A.; Bourdeau, M.J.; Pillar, L.L. Treating an electrocoat system with a biosurfactant 2008. US7413643B2, 2008.

195.Reid, G.; Bruce, A.W.; Busscher, H.J.; Van Der Mei, H.C. Lactobacillus therapies 2000. US6051552A, 2000.

196.Mitra, D.; Kang, E.-T.; Neoh, K.G. Applications and challenges of smart antibacterial coatings. In Advances in Smart Coatings and Thin Films for Future Industrial and Biomedical Engineering Applications; Elsevier, 2020; 537-556, https://doi.org/10.1016/B978-0-12-849870-5.00013-6 